\title{
Análise Econômica do Direito e o Crédito Tributário na Recuperação Judicial
}

\author{
Economic Analysis of LaW AND tax CRedit in \\ Judicial Recovery
}

\section{AnÁlisis Económico de Derecho y Crédito Tributario en ReCUPERACión JUdicial}

Henrique Avelino Lana*

Eduardo Goulart Pimenta*

1 Introdução. 2 O cuidado especial dado ao credor tributário. 3 A problemática exigência de certidões. 4 Reflexões sobre o parcelamento como condição para aprovação do plano de recuperação: aparente ineficiência. 5 Inaplicabilidade constitucional, legal, operacional e prática: ineficiência e alto custo de transação. 6 Conclusão. Referências.

\section{RESUMO}

Objetivo: Busca-se, via Análise Econômica do Direito, identificar, de forma construtiva, sem almejar esgotar o tema, que a atual redação da Lei 11.101/05, no que se refere sobre o crédito tributário, contribui para a sua ineficiência.

Metodologia: A metodologia a ser utilizada é o método dedutivo, mediante abordagem explicativa e descritiva, com pesquisa jurisprudencial e bibliográfica, nacional e estrangeira, toda ela especializada no cerne do tema. O problema específico a ser levantando é saber se seria possível incluir o crédito tributário no plano de recuperação judicial. Para obter-se uma resposta que seja técnica, prática e acadêmica, inicialmente,

* Pós Doutorando, Doutor, Mestre e Especialista em Direito pela Pontifícia Universidade Católica de Minas Gerais, MG, BR. Email: <henriqueavel@hotmail.com>. https://orcid.org/0000-0001-7867-0563

** Doutor e Mestre pela UFMG. Procurador. Professor da PUC e UFMG. https://orcid.org/0000-0002$6526-9858$ 
será explicado sobre o tratamento especial dado ao crédito tributário na Lei 11.101/05.

Resultados: Após, será mostrado que o poder e privilégio concedido ao Fisco, frise-se, tal como está, nos termos literais da lei, nos processos de recuperação judicial, é ineficiente e, que, as condições de parcelamento que vigoraram por muitos anos também não eram eficientes. No mesmo sentido, serão expostos os motivos que denotam que a legislação atual não cria incentivos positivos ao contribuinte a aderir tal parcelamento. Ao final, como hipótese de resposta, serão também abordados os motivos que fazem que em nosso ordenamento seja impossível, legalmente, operacionalmente e constitucionalmente, a inclusão no plano de recuperação dos créditos tributários, haja vista o alto custo de transação.

Contribuições: Verifica-se que o poder e privilégio concedido ao Fisco, frise-se, tal como está, nos termos literais da lei, nos processos de recuperação judicial, é ineficiente. As condições de parcelamento que vigoraram por muitos anos também não eram eficientes. A legislação atual não cria incentivos positivos ao contribuinte a aderir tal parcelamento. Atualmente, em nosso ordenamento, é impossivel, legalmente, operacionalmente e constitucionalmente, a inclusão no plano de recuperação dos créditos tributários, haja vista o alto custo de transação.

Palavras-chave: Crédito Tributário. Recuperação Judicial. Análise Econômica do Direito.

\section{ABSTRACT}

Objective: We seek, through Economic Analysis of Law, to identify, in a constructive way, without aiming at exhausting the theme, that the current wording of Law 11.101/ 05, with regard to tax credit, contributes to its inefficiency.

Methodology: The methodology to be used is a deductive method, by means of an explanatory and descriptive approach, with jurisprudential and bibliographic research, national and foreign, all specialized in the core of the theme. The specific problem to be raised is whether it would be possible to include the tax credit in the judicial reorganization plan. To obtain a response that is technical, practical and academic, initially, it will be explained about the special treatment given to tax credit in Law $11.101 / 05$.

Results: Afterwards, it will be shown that the power and privilege granted to the Tax Authorities, as it stands, in the literal terms of the law, in the judicial reorganization processes, is inefficient and that the installment conditions that were in force for many years they were also not efficient. In the same sense, the reasons that show that the 
current legislation does not create positive incentives for the taxpayer to join such installment will be exposed. In the end, as a response hypothesis, the reasons that make it impossible, legally, operationally and constitutionally, to include in the tax credit recovery plan, in view of the high transaction cost, will also be addressed.

Contributions: It appears that the power and privilege granted to the Tax Authorities, as it stands, in the literal terms of the law, in judicial reorganization processes, is inefficient. The installment terms that prevailed for many years were also not efficient. Current legislation does not create positive incentives for taxpayers to adhere to such installments. Currently, in our law, it is impossible, legally, operationally and constitutionally, to include in the tax credit recovery plan, given the high transaction cost.

Keywords: Tax Credit. Judicial recovery. Economic Analysis of Law.

\section{RESUMEN}

Objetivo: Buscamos, a través del Análisis Económico del Derecho, identificar, de manera constructiva, sin pretender agotar el tema, que la redacción actual de la Ley $11.101 / 05$, en materia de crédito fiscal, contribuye a su ineficiencia.

Metodología: La metodología a utilizar es un método deductivo, mediante un enfoque explicativo y descriptivo, con investigación jurisprudencial y bibliográfica, nacional y extranjera, todo ello especializado en el núcleo de la temática. El problema específico que se plantea es si sería posible incluir el crédito fiscal en el plan de saneamiento judicial. Para obtener una respuesta técnica, práctica y académica, inicialmente se explicará el tratamiento especial que se le da al crédito tributario en la Ley 11.101/ 05.

Resultados: Posteriormente se demostrará que el poder y privilegio otorgado a las Autoridades Tributarias, tal como está, en los términos literales de la ley, en los procesos de reorganización judicial, es ineficiente y que las condiciones de pago que estuvieron vigentes durante muchos años tampoco eran eficientes. En el mismo sentido, se expondrán las razones que demuestran que la legislación vigente no crea incentivos positivos para que el contribuyente se una a dicha cuota. Al final, como hipótesis de respuesta, también se abordarán las razones que imposibilitan, legal, operacional y constitucionalmente, incluir en el plan de recuperación de crédito tributario, dado el alto costo de transacción.

Contribuciones: Parece que el poder y privilegio otorgado a las Autoridades Tributarias, tal como está, en los términos literales de la ley, en los procesos de reorganización judicial, es ineficiente. Los plazos de pago que prevalecieron durante muchos años 
tampoco fueron eficientes. La legislación actual no crea incentivos positivos para que los contribuyentes se adhieran a dichas cuotas. Actualmente, en nuestra legislación es imposible, legal, operacional y constitucionalmente, incluir en el plan de recuperación de crédito tributario, dado el alto costo de transacción.

Palabras clave: Crédito Fiscal. Recuperación judicial. Análisis económico del derecho.

\section{INTRODUÇÃO}

A Lei 11.101/05 permite que alguns credores não se submetam ao plano de recuperação. Assim, as execuções individuais movidas por tais credores ficam suspensas durante o prazo do stay de 180 dias contados a partir do deferimento do trâmite do processo de recuperação. Após tal prazo, tendo sido concedida a recuperação, ou não, poderão tais credores executar seu crédito, a não ser em caso de falência. Tais hipóteses de credores estão expressamente previstas no artigo 49, parágrafos terceiro e quarto. ${ }^{1}$

Mas outra interessante previsão é dada de forma especial em relação às execuções fiscais, as quais, além estas, além de não se submeterem ao concurso na recuperação judicial, não sofrem os efeitos da concessão da recuperação judicial. Nesses casos, cumprirá ao recuperando quitar o seu crédito tributário ou parcelá-lo administrativamente, entre a data do pedido de recuperação e a juntada aos autos do plano de recuperação, nos literais termos da Lei. ${ }^{2-3}$ Há também tal exigência na Lei

\footnotetext{
1 "Art. 49. Estão sujeitos à recuperação judicial todos os créditos existentes na data do pedido, ainda que não vencidos. $\S 3^{\circ}$ Tratando-se de credor titular da posição de proprietário fiduciário de bens móveis ou imóveis, de arrendador mercantil, de proprietário ou promitente vendedor de imóvel cujos respectivos contratos contenham cláusula de irrevogabilidade ou irretratabilidade, inclusive em incorporações imobiliárias, ou de proprietário em contrato de venda com reserva de domínio, seu crédito não se submeterá aos efeitos da recuperação judicial e prevalecerão os direitos de propriedade sobre a coisa e as condições contratuais, observada a legislação respectiva, não se permitindo, contudo, durante o prazo de suspensão a que se refere o $\S 4$ o do art. 6o desta Lei, a venda ou a retirada do estabelecimento do devedor dos bens de capital essenciais a sua atividade empresarial. § 4o Não se sujeitará aos efeitos da recuperação judicial a importância a que se refere o inciso II do art. 86 desta Lei." (BRASIL, 2005, online).

2 O foco que está sendo dado é relativo à literalidade da lei. Sabe-se, por outro lado, que existem decisões judiciais que, em determinados casos, flexibilizam tal imposição legal.

3 "Art. $6^{\circ}$ A decretação da falência ou o deferimento do processamento da recuperação judicial suspende o curso da prescrição e de todas as ações e execuções em face do devedor, inclusive aquelas dos credores particulares do sócio solidário. [...] § $7^{\circ}$ As execuções de natureza fiscal não são suspensas pelo deferimento da recuperação judicial, ressalvada a concessão de parcelamento nos termos do Código Tributário Nacional e da legislação ordinária específica. Art. 57. Após a juntada aos autos do plano aprovado pela assembléia-geral de credores ou decorrido o prazo previsto no art. 55 desta Lei sem objeção de credores, o devedor apresentará certidões negativas de débitos tributários nos termos dos arts. 151, 205, 206 da Lei $n^{\circ}$ 5.172, de 25 de outubro de 1966 - Código Tributário Nacional." (BRASIL, 2005, online).
}

36 R. Opin. Jur., Fortaleza, ano 19, n. 31, p.33-74, maio/ago. 2021 
5.172/66, contendo a redação da Lei Complementar 118/2005. ${ }^{4}$ Antes da Lei 11.101/05, o prazo para apresentação de certidões negativas de débitos tributários, no Decreto Lei 7.661/45, era maior do que na atual lei. Na vigência da legislação anterior, consoante ao artigo 174, inciso I, do Decreto - Lei n. ${ }^{\circ} 7661 / 45$, as certidões negativas de débito fiscal somente eram exigidas ao final da concordata, cujo prazo máximo era de dois anos, tendo o devedor um lapso temporal bem maior do que o estabelecido pela atual legislação para que pudesse quitar suas dívidas tributárias (LOPES, 2008, p. 208).

Assim, este artigo tem o objetivo, via Análise Econômica do Direito, de identificar, de forma construtiva, sem almejar esgotar o tema, se a atual redação da Lei 11.101/05, no que se refere sobre o crédito tributário, contribui ou não para a sua ineficiência. A metodologia a ser utilizada é o método dedutivo, mediante abordagem explicativa e descritiva, com pesquisa jurisprudencial e bibliográfica, nacional e estrangeira, toda ela especializada no cerne do tema. $O$ problema específico a ser levantado é saber se seria possível incluir o crédito tributário no plano de recuperação judicial. Para obter-se uma resposta que seja técnica, prática e acadêmica, inicialmente, será explicado sobre o tratamento especial dado ao crédito tributário na Lei 11.101/05. Após, cuidar-se-á da ineficiência do poder e privilégio concedido ao Fisco, bem como das ineficientes condições de parcelamento que vigoraram por muitos anos.

A seguir, serão expostos os motivos que autorizam denotar que a legislação atual não cria incentivos positivos ao contribuinte a parcelamento do crédito tributário. Ao final, como hipótese de resposta, serão também abordados os motivos que fazem que, em nosso ordenamento atual seja impossível, legalmente, operacionalmente e constitucionalmente, a inclusão no plano de recuperação dos créditos tributários, haja vista o alto custo de transação.

\section{O CUIDADO ESPECIAL DADO AO CREDOR TRIBUTÁRIO}

Para se compreenderem tais privilégios dos credores tributários, deve-se ter em mente, desde já, que os credores quirografários, como regra, exigem encargos maiores em razão do risco que correm, enquanto os credores com direito real de garantia oferecem crédito mais barato em razão da garantia e, consequentemente, do menor risco de prejuízo em caso de falência. Quanto maior a garantia, menor o custo (LÓPEZ-IBOR; ARTÉS-CASELLES, 2003, p. 4). López-Ibor e Artés-Caselles (2003), em estudo

\footnotetext{
4 “Art. 187. A cobrança judicial do crédito tributário não é sujeita a concurso de credores ou habilitação em falência, recuperação judicial, concordata, inventário ou arrolamento. (Redação dada pela LC n ${ }^{\circ}$ 118, de 2005) Art. 191-A. A concessão de recuperação judicial depende da apresentação da prova de quitação de todos os tributos, observado o disposto nos arts. 151, 205 e 206 desta Lei (Incluído pela LC no 118, de 2005)." (BRASIL, 1966, online).
} 
específico sobre o tema, apontam algumas razões, de natureza eminentemente econômica, que explicariam o oferecimento de garantias, por parte dos devedores em geral, aos credores, quais sejam,

a) "custos de supervisão": os credores não detentores de privilégio concursal não têm como prevenir-se diante da redução do ativo do devedor, enquanto o credor que tenha garantia real pode perseguir a coisa onde quer que se encontre;

b) "redução da informação assimétrica": ao oferecer um bem em garantia, a empresa devedora revela estar convencida do êxito de seu projeto, gerando, a favor da negociação, uma redução da assimetria da informação;

c) "uso de método eficiente de financiamento": os custos de um empréstimo com garantias são inferiores. O devedor, por razões econômicas, deve obtê-lo em primeiro lugar, deixando para depois as linhas de crédito mais caras (LÓPEZ - ÍBOR; ARTÉS-CASELLES, 2003, p. 4-8).

Considerando-se que a Fazenda Pública não possui relação com o contribuinte, que se estabeleça mediante tais pressupostos, há o argumento de que se deve dar maior privilégio ao crédito tributário. Segundo tais autores, são quatro os argumentos utilizados para defender a prioridade de tratamento quanto aos créditos tributários:

a) não se pode prover de direito real de garantia para satisfação de seus créditos;

b) não pode adequar os encargos aos riscos das novas contratações;

c) não pode escolher seus devedores. Todas as empresas são potencialmente devedoras do governo;

d) trabalha para o interesse público, em benefício da sociedade, na qual estão incluídos os credores quirografários (LÓPEZ - ÍBOR; ARTÉS-CASELLES, 2003, p. 9).

Rocio López-ibor e Joaquín Artés-Caselles analisam os riscos de mercado, bem como a maior ou menor desenvoltura para proteger seu investimento, por parte dos credores. (LÓPEZ-ÍBOR; ARTÉS-CASELLES, 2003, p. 11). Para eles, os credores que não são de natureza tributária se submetem a quatro tipos de riscos no mercado:

a) riscos de natureza pessoal: são os riscos evitados pela obtenção de maiores informações do cliente, como, por exemplo, exigência de cadastros atualizados e, no Brasil, consulta ao Sisbacen;

b) riscos sobre a carteira de clientes: para evitar a concentração em um só segmento de mercado, o financiador pode diversificar seus investimentos, selecionando novos clientes e empresas;

c) riscos de mercado: a diversificação em vários setores da atividade ameniza os riscos de um colapso econômico em um setor específico da economia; 
d) riscos globais: não há proteção aos riscos que atingem toda a economia de um país, salvo se a credora for empresa multinacional e operar em diferentes países (LÓPEZ-ÍBOR; ARTÉS-CASELLES, 2003, p. 11).

Entende-se que, em relação ao primeiro item, todos os credores, que não são de natureza tributária, como regra, têm possibilidade de evitar os riscos das perdas mediante busca de maiores e mais completas informações de seus parceiros em transações comerciais.

No entanto, entende-se que em relação ao segundo item, nem todos, que não são de natureza tributária, podem diversificar a carteira de risco ou transferir-se para outro setor de mercado, tal como, os credores trabalhistas e os pequenos fornecedores, os quais, devido à especialidade relativa aos seus produtos e serviços ou, até mesmo, à sua localização, ficam impedidos de assim fazer. Já em relação ao terceiro item, a Fazenda Pública, ela sim, possui a carteira mais diversificada, pois abrange todos os segmentos da sociedade, inclusive podendo superar as perdas e os prejuízos de um setor, diante de um bom desempenho de outro setor. Somente o risco global (quarto item) atinge a todos. E é por esse motivo (possuir a carteira mais diversificada) que a Fazenda Pública já teria, em si, situação favorável. Portanto, a Fazenda Pública, também para tais autores, já possuiria adequadas vantagens em relação a outros credores, por isso não se justificariam outros privilégios lhe serem concedidos.

Uma das explicações mais comuns é a de que o Erário é incapaz de ajustar sua avaliação no caso de um devedor em crescente grau de risco. Contudo, tendo em vista que o Erário possui uma carteira de títulos muito diversificada, dispõe de grande vantagem em comparação com dos demais credores quanto à cobertura de natureza pessoal, carteira de clientela e riscos de mercado. Em nossa opinião, esta vantagem é suficiente para compensar sua incapacidade de ajustar os prêmios à real situação de ampliação no grau de risco do devedor. Consequentemente, consideramos que os privilégios do Erário não podem ser baseados neste tipo de argumento (LÓPEZ-ÍBOR; ARTÉS-CASELLES, 2003, p. 15 , tradução nossa). ${ }^{5}$

Diante disso, os referidos autores acreditam, portanto, que a extinção do tratamento especial e privilegiado da Fazenda Pública se mostraria mais eficiente. Isso acabaria por incentivar e estimular a atividade econômica, em sua totalidade, e está em consonância com os objetivos do legislador previstos no artigo 47 da Lei 11.101/05 ${ }^{6}$.

${ }^{5}$ One of the usual explanation has been that the public treasury was enable to adjust its risk premium to meet an increased debtor risk but, since the Public Treasury's portfolio is completely diversified, is has a comparative advantage over other possible creditors when covering personal, portfolio and market risks. In our opinion, this advantage is sufficient to make up for its being unable to adjust its risk premiums when the risk of default on the part of one of its debtors increases. We therefore consider that privileges for the Public Treasury cannot be based on this type of argument.

6 "Art. 47. A recuperação judicial tem por objetivo viabilizar a superação da situação de crise econômicofinanceira do devedor, a fim de permitir a manutenção da fonte produtora, do emprego dos 
Ao ser tratado como credor comum sujeito à recuperação, a Fazenda Pública, em sua nova posição, contribui com todos os demais credores do empresário em crise econômica e, de maneira diversificada e, ademais, proporciona retorno via arrecadação em relação à atividade dos credores beneficiados (LÓPEZ-ÍBOR; ARTÉS-CASELLES, 2003, p. 16). Para Lopes (2008):

Em um primeiro momento, parece que o legislador quis impedir a concessão da recuperação judicial ao empresário ou sociedade empresária que esteja em dívida com a Fazenda Pública, resguardando novamente, os interesses da Administração Tributária. No entanto, efetuando uma análise econômica da questão, verifica-se que, se realmente essa foi a intenção do legislador, ela poderá causar reflexos negativos aos interesses da Fazenda Pública (LOPES, 2008, p. 204).

Nesse diapasão, levando-se em consideração os objetivos econômicos da novel legislação, a inviabilização da concessão da recuperação judicial em face da existência de dívidas tributárias impedirá o soerguimento da empresa no mercado, acarretando a própria impossibilidade de se efetivar o pagamento do crédito tributário. Faz-se cogente, portanto, o dever do Estado de contribuir na recuperação da empresa em crise, não se justificando que a existência de débito tributário possa constituir impedimento ao desenvolvimento do processo de recuperação judicial de empresas, ensejando a decretação da falência (LOPES, 2008, p. 205).

Verifica-se, portanto, que a eficiência de um sistema concursal tem íntima relação com os objetivos econômicos a serem alcançados pela norma jurídica, devendo o operador do Direito considerar os fatores institucionais, econômicos e legais que influenciam a sua aplicação. Nesse cenário, é primordial que o operador do Direito perceba algumas similitudes entre as hipóteses que, apesar de terem tratamento jurídico diferenciado pela Lei, representam formas de reorganização societária passíveis de terem o mesmo tratamento tributário. A nova legislação deve ser interpretada levando em consideração o binômio eficiência econômica e função social, no objetivo de superar as conjunturas adversas à continuidade do exercício da atividade empresarial e permitir o saneamento das empresas economicamente viáveis, que exercem um papel relevante no cenário jurídico - econômico (LOPES, 2008, p. 191).

Qualquer exigência ou medida, prevista na legislação, visando a reduzir a possibilidade de perda do direito ao recebimento do crédito tributário, é uma garantia deste. Numa visão abrangente, todo dispositivo legal que tenha como objetivo, ou como consequência, dar mais eficácia e efetividade ao direito do Estado de exigir o cumprimento da obrigação principal é uma garantia do crédito, independentemente de estar ou não referida no capítulo VI, título III, do Código Tributário Nacional (MACHADO, 1984, p. 21-22). No mesmo sentido:

trabalhadores e dos interesses dos credores, promovendo, assim, a preservação da empresa, sua função social e o estímulo à atividade econômica." (BRASIL, 2005, online). 
É de se considerar ainda a existência de fundamentos econômicos voltados à extinção destes privilégios, baseados nos dois argumentos ora apresentados. Inicialmente, verifica-se que o proveito para o bem comum é maior que o proveito exclusivo dado ao Erário, uma vez que o proveito marginal dos credores comuns que receberão pagamento será normalmente maior que o do Governo nos referidos pagamentos. Tal fato se dá em razão de os valores recebidos pelo Erário nos processos de falência representarem uma pequena parte de sua receita em comparação com os pagamentos realizados por pequenos credores nos processos falimentares. Em segundo lugar, o Erário é credor tanto da empresa falida quanto dos demais credores. Isso significa que alguns prejuízos que vier a sofrer serão atenuados pelo recebimento dos impostos advindos dos credores comuns que se beneficiam da extinção dos privilégios. Assim, é possível concluir que a extinção dos privilégios defendidos pela Fazenda Pública poderia ser eficiente do ponto de vista econômico, embora se reconheça a existência de razões legais para a manutenção desses privilégios ao Erário. As razões acima mencionadas seguem a linha das recentes alterações legislativas ocorridas em Portugal e Alemanha, e representam uma crítica as reformas propostas pela Lei falimentar da Espanha. Embora o preâmbulo da Lei norte-americana preveja que os privilégios do Erário devam ser extintos, o artigo 90.3 mantém referido privilégio em até $50 \%$ dos seus créditos. Finalmente, a título de pesquisa adicional, seria importante determinar as porcentagens exatas do débito reconhecido para credores na falência, a fim de acertar a posição e as taxas da recuperação para cada credor em referidos processos falimentares (LÓPEZÍBOR; ARTÉS-CASELLES, 2003, p. 16, tradução nossa). ${ }^{7}$

Não há dúvidas acerca da importância do crédito tributário a ser pago, inclusive, para o próprio Estado. Acredita-se, inclusive, que, em regra, nos momentos de crise econômica e financeira, o Estado seja o maior credor no Brasil. Tal fato é, muitas vezes ponderado, pelos doutrinadores quando da abordagem acerca da comprovação de quitação tributária, como requisito legal, literal, para o êxito da recuperação. Para Lopes

${ }^{7}$ We also consider that there are economic arguments in favour of abolishing these privileges. These are based on two related arguments. Firstly, total social utility is greater than the Public Treasury's utility because the marginal utility for ordinary creditors of receiving payment will normally be greater than the Government's marginal utility of receiving its payments. This is because funds received by the Treasury in bankruptcy processes usually represent a small percentage of its revenue in comparison with the payments made in bankrupticies to small creditors. Secondly, the Public Treasury is a creditor for the bankrupt company but at the same time it is a creditor for all the other creditors. This means that any losses it suffers if its privileges are abolished will be attenuated because it will subsequently receive taxes paid out of the amounts received by the ordinary creditors who benefit from the abolition. It can therefore be concluded that abolition of the privileges enjoyed by the Public Treasury could be efficient from the economic point of view, although there may be legal reasons to support such privileges for the Treasury. The above reasons are in line with recent legislative developments in Portugal and Germany, and represent a criticism of the reforms under way in Spanish bankruptcy law. Although the preamble of the bill of law States that the privileges of the Public Treasury should be abolished, article 90.3 maintains its privileges up to $50 \%$ of its credits. Finally, for the purpose of further research, it would be useful to determine the exact percentages of debt acknowledged for creditors in bankruptcies in order to ascertain the position and rates of recovery for each creditor in such processes. 
(2008, p. 217): "Entre os credores do devedor em recuperação judicial, o Estado, detentor do crédito tributário, é quem tem maior interesse em viabilizar a recuperação da empresa, preservando sua unidade produtiva, de maneira que possa alcançar sua função social.” Para o mesmo autor:

Como afirma Hugo de Brito, "o passivo tributário constitui um grave problema de recuperação de empresas", visto que a elevada carga tributária vigente em nossa legislação tem grande contribuição para o agravamento da situação de crise das empresas, quando não é causa exclusiva dela. No processo de falência e recuperação de empresas o Estado, além de figurar como credor, deve zelar pela forma mais eficiente de recuperar a empresa ou liquidar seus ativos, tendo o dever de agir em prol de seu restabelecimento no mercado, caso seja economicamente viável, em face do interesse público que cerca o assunto (LOPES, 2008, p. 203).

Para Santos Júnior (2010, p. 39):

A experiência comum revela que empresas em situação de crise econômica financeira sempre apresentam débitos tributários. É fato notório que o empresário ou sociedade empresária utiliza uma escala de preferências numa situação de crise econômico financeira, atrasando primeiro o pagamento dos tributos, em seguida os quirografários e, por último, os direitos trabalhistas, de sorte que, na prática, não haverá devedor em recuperação que não apresente débitos fiscais.

Para Machado (2005, p. 77):

Sabemos todos que o passivo tributário constitui um grave problema para a sobrevivência de um grande número de empresas. Essa é uma realidade que não podemos desconhecer, até por que as próprias leis, cuidando de parcelamentos, de dívidas tributárias, e a enorme quantidade de empresas que se valem desses parcelamentos nos oferecem demonstração incontestável. Não estaremos exagerando se afirmarmos que em um processo de recuperação de empresas, como o previsto na Lei 11.101, de 9 de fevereiro de 2005, o dado mais preocupante é composto precisamente pelas dividas tributárias. Podemos dizer mesmo que todas as empresas que estão a necessitar da aplicação dessa lei possuem grande passivo tributário, e que sem a superação desse problema nenhuma delas será superada. Aliás, existem empresas em dificuldades financeiras das quais o Fisco é praticamente o único credor, vale dizer, o Fisco é o único credor de montante expressivo. O passivo tributário dessas empresas geralmente é superior a oitenta por cento do passivo total.

Para Proença (2005, p. 640, grifo do autor):

Não há dúvidas de que a obrigação da apresentação das certidões de débitos tributários (negativa ou positiva com efeito de negativa) pode dificultar a recuperação da empresa, e após todo o procedimento ocorrido até a aprovação 
do plano de recuperação pela assembleia geral de credores, poderá tornar sem efeito aquilo que já foi realizado no processamento da recuperação, colocando em risco o objetivo primordial do novo direito concursal em recuperar empresas viáveis, principalmente quando se nota que a quase totalidade das empresas no país, detentoras de volumoso passivo têm, entre seus principais credores, o Fisco.

Para Salomão e Santos (2015, online, grifo do autor):

O plano de recuperação da empresa é o verdadeiro coração da nova lei, porém uma questão sempre existiu e permanece existindo, que é a melhor equalização da questão tributária para o devedor em crise. Desde a sua vigência, as modificações decorrentes da aplicação da nova lei estão sendo observadas. Celeridade para concessão da medida, recuperação de ativos, satisfação do crédito trabalhista, eficácia da manutenção da atividade econômica, desburocratização em relação ao micro e pequeno empresário, punição rigorosa de crimes falimentares, enfim, muitos princípios da nova lei demandam observação atenta. Interessante estudo da FGV/Rio, junto com o Ministério da Justiça, publicado em junho de 2010, da série "Pensando o Direito", apresenta pesquisa séria sobre diversos destes temas, baseado em dados de Tribunais coletados em diversos estados da federação. Com efeito, um dos maiores problemas para a empresa que pretende obter ou está em recuperação judicial foi e continua sendo seu passivo tributário (art. 57 e 68 da Lei n. 11.101/05). Na verdade, compete ao Judiciário equilibrar os interesses em conflito, notadamente entre o soerguimento pretendido pela empresa que busca a recuperação (empregos, aquecimento econômico), e o interesse público para recebimento dos tributos devidos (saúde, educação, segurança, por exemplo).

Há doutrinadores que defendem a inclusão do crédito tributário na recuperação judicial e seus efeitos. Veja-se:

Seria inconstitucional a exclusão do crédito tributário dos processos de recuperação de empresas? O credor tributário dá ao empresário um "presente de grego" para sua recuperação, pois ele estará excluído de qualquer processo de recuperação, seja judicial como extrajudicial. $O$ seu discurso para não ser incluído é: o crédito fiscal não pode estar incluído na recuperação porque ele visa atender ao interesse público da coletividade! Isto faz com que ele possa continuar cobrando seus créditos sem participar da negociação de dívidas que é feita pelo empresário devedor com os demais credores que não tem este privilégio. Isto demonstra que quem não oferece nada diretamente ao empresário em dificuldades é super privilegiado, o que parece contrariar qualquer raciocínio lógico. [...] É preciso sabermos de onde vem esta lei de recuperação de empresas para que se possa entendê-la melhor. Nossa legislação de recuperação de empresas e falências foi baseada em grande parte no processo de recuperação utilizado na França. Na França houve uma discussão se a lei de recuperação de empresas e falências, conhecida por redressement judiciaire e faillite, seria aplicada ao credor tributário. Após várias discussões na doutrina e na jurisprudência, chegou a conclusão que seria. [...]Entendemos que no Brasil os processos de recuperação também 
deveriam incluir todos os créditos, incluindo o crédito tributário, porque ao ser mantida uma empresa em atividade com a inclusão do crédito tributário haverá maior possibilidade do empresário se recuperar e sua recuperação, da mesma forma que o crédito tributário, são questões de interesse público! Sendo as duas questões de interesse público: o recebimento do tributo e a preservação da empresa, o melhor caminho parece ser que todos os interessados (fisco, trabalhadores e demais credores) decidam o destino da empresa, parecendo ser inconstitucional a exclusão do fisco dos processo de recuperação judicial e extrajudicial (ZANETTI, 2000, p. 70, grifo nosso). ${ }^{8}$

O mesmo Autor salienta:

A discussão merece aqui ser reproduzida porque pode ser fundamental para sua aplicação no Brasil. O professor Bernard Soinne (um dos maiores especialistas na França na matéria) criticava a posição que defendia a concessão de prazos de pagamentos para os créditos fiscais porque, segundo ele, o processo de regulamento amigável (no Brasil este processo é semelhante a recuperação extrajudicial e judicial) é essencialmente convencional e a lei não permite que seja derrogado oprincípio da separação de funções administrativa e judicial que vetava ao magistrado conceder prazos para o devedor pagar seus débitos. O professor Derrida, outro grande especialista, ao contrário do que afirmava o professor Soinne, entendia que o processo de recuperação é igualmente um processo de ordem pública que permite derrogar as disposições gerais da legislação tributária em vista de assegurar a finalidade do processo de recuperação das empresas, ou seja, recuperar o empresário em dificuldades (ZANETTI, 2000, p. 71-72).

No mesmo sentido:

O fisco deveria dar a sua contribuição para a recuperação da empresa, abrindo mão de seus privilégios, pois em tese a Fazenda/Governo são os maiores interessados na manutenção de uma unidade produtiva e deveriam oferecer uma maior dose de sacrifício para apoiar sua recuperação, e não o contrário (MANDEL, 2005, 134-135, grifo do autor).

É lamentável que o novo instituto da recuperação, de tanta relevância social, possa não ter incluído os créditos tributários dentre aqueles sujeitos à sua jurisdição. Como solucionar a situação de uma empresa em crise se o seu passivo fiscal fica à margem do processo? Sabidamente, quando o empresário encontra-se em dificuldades financeiras, são exatamente os tributos e encargos financeiros aqueles que primeiro deixam de ser pagos ou recolhidos. Pretender resolver a crise da empresa sem que a Fazenda Pública possa dar a sua contribuição é um retrocesso. Se a empresa tem uma função social a ser preservada, o Estado deve ser o primeiro interessado na manutenção da atividade produtiva, na manutenção dos empregos e no aumento da

${ }^{8}$ Robson Zanetti é advogado, Doctorat Droit Privé pela Université de Paris 1 Panthéon-Sorbonne. Corso Singolo em Diritto Processuale Civile e Diritto Fallimentare pela Università degli Studi di Milano. Autor de mais de 150 artigos, das obras Manual da Sociedade Limitada: Prefácio da Ministra do Superior Tribunal de Justiça Fátima Nancy Andrighi ; A prevenção de Dificuldades e Recuperação de Empresas e Assédio Moral no Trabalho (E-book). É também juiz arbitral e palestrante. 
arrecadação. É inconcebível que o Fisco, além de não contribuir para a recuperação, frise-se, coloque em risco o salvamento da empresa, caso o parcelamento, conforme previsto no art. 68, não seja deferido. Tal postura não se coaduna com o Estado moderno voltado para os interesses sociais (GUIMARÃES, 2007a, p. 275).

É nesse ponto que se encontra o contra entrave da Lei, já que dentre o passivo da empresa significativa parte corresponde aos débitos fiscais, tendo em vista a insuportável carga tributária direta e indireta suportada pelo empresariado. É justamente sob esse prisma, o ponto que trazemos à discussão, pois afigura-se desmotivado exigir, para a viabilidade do plano de recuperação judicial, a prova da regularidade dos créditos fiscais. Não é possível se imaginar uma plena recuperação judicial se os principais credores, as Fazendas Públicas, não estiverem sujeitos ou não gozarem de certa autonomia para aceitar ou negociar o plano apresentado pela empresa. No mínimo essa exigência se torna contraditória ao principal objetivo da Recuperação Judicial, ou seja, daquilo que pretendeu o legislador, recuperação e manutenção da sociedade devedora, exigir a demonstração da regularidade fiscal da empresa, através de apresentação de CND, para que seja viabilizada a sua recuperação judicial. Como fazer um plano de recuperação judicial sem que seja feita a inclusão dos créditos fiscais no plano de reestruturação, já que na maioria das vezes o Fisco é o grande credor? (BRANQUINHO; CREMONINI, 2016, online, grifo do autor).

A exclusão do Estado de todo o processo de recuperação judicial recebeu protestos da doutrina. Se ao próprio Estado interessa a recuperação, é forte o entendimento pelo qual também deveria lhe caber certa dose de sacrifício, sendo dever estatal evitar o fim da atividade econômica capaz de produzir dividendos sociais (BARROS NETO, 2012, p. 71, grifo nosso).

A Lei 11.101/05 impõe o privilégio de se executar livremente o crédito fiscal. O artigo $57^{9}$ enseja também, por sua leitura literal, ampla discussão, pois trata da necessidade de pagamento do crédito tributário, mediante apresentação de certidão comprobatória. ${ }^{10}$ Por outro lado, entende-se que esse privilégio aumenta o custo de transação e não é eficiente.

Questão das mais importantes a ser discutida, em face da sua relevância no saneamento da situação de crise econômica, financeira e patrimonial do devedor é o parcelamento do crédito tributário na recuperação judicial de empresas, que é tratado pelo artigo 57 da Lei 11.101/2005 e pelo artigo 191-A do Código Tributário Nacional. Este último preceitua que o devedor deverá apresentar certidões negativas de débito tributário para que seja concedida

9 "Art. 57. Após a juntada aos autos do plano aprovado pela assembléia-geral de credores ou decorrido o prazo previsto no art. 55 desta Lei sem objeção de credores, o devedor apresentará certidões negativas de débitos tributários nos termos dos arts. 151, 205, 206 da Lei n ${ }^{\circ} 5.172$, de 25 de outubro de 1966 . Código Tributário Nacional." (BRASIL, 2005, online).

${ }^{10}$ Sobre a relevância dos créditos tributários e a crise das empresas no Brasil, vide: Secretaria de Assuntos legislativos do Ministério da Justiça. Fundação Getúlio Vargas. Relatório Final de Pesquisa do Projeto Pensando Direito: avaliação da nova lei de falências (Lei 11.101/05). Maio de 2010 (BRASIL, 2005). 
recuperação judicial da empresa. Já o artigo 155-A § 3o do Código Tributário Nacional, determina a elaboração de Lei específica que disponha sobre as condições do parcelamento dos créditos tributários do devedor em recuperação judicial (LOPES, 2008, p. 203).

Nas palavras de Mandel (2005, p. 134-135, grifo nosso):

Fica criada uma proteção injustificável para a Fazenda Pública, proteção essa nociva aos interesses da Lei, que é a manutenção da unidade produtiva, pois na prática exclui os créditos fiscais da recuperação judicial (o que não acontece com nenhum outro credor), quando se sabe que uma das maiores causas da ruína das empresas é justamente a alta carga tributária. [...] $]$ prosseguimento da execução fiscal com a penhora de bens da empresa devedora, durante o prazo de negociação do plano de recuperação com os demais credores poderá inviabilizar a recuperação.

\section{Para Lopes (2008):}

Essa dualidade de processos tramitando simultaneamente dá margem a interpretações diversas, ocasionando insegurança jurídica, que pode ser prejudicial ao sistema de insolvência empresarial. Referida insegurança surge em face da dificuldade em se garantir a correta distribuição dos valores auferidos com a alienação dos ativos do devedor, em estrita observância ao artigo 83 da Lei n. ${ }^{\circ} 11.101 / 05$. Apesar de haver entendimento jurisprudencial predominante no sentido de que os bens penhorados ou arrestados em execução fiscal não são passíveis de arrecadação pelo administrador judicial da falência, devendo o produto da alienação destes bens no Juízo Fiscal ser colocado à disposição do Juízo Falimentar, há uma imensa dificuldade prática na obtenção desse sincronismo processual (LOPES, 2008, p. 124, grifo nosso).

No processo de recuperação judicial de empresa, há uma dualidade de interesses que a legislação pretende proteger. De um lado, encontra-se o interesse individual do empresário ou sociedade empresária, de outro, um interesse maior, de ordem social e econômica. Esse dualismo não tem convivência harmoniosa, sendo prejudicial ao sistema como um todo, sob a ótica econômica (LOPES, 2008, p. 204).

\section{Nas palavras de Comparato (1970):}

O mínimo que se pode dizer nessa matéria é que o dualismo no qual se encetou o nosso direito falimentar - proteger o interesse pessoal do devedor ou o interesse dos credores - não é de molde a propiciar soluções harmoniosas no plano geral da economia. O legislador parece desconhecer totalmente a realidade da empresa, como centro de múltiplos interesses - do empresário, dos empregados, dos sócios capitalistas, dos credores, do fisco, da região, do mercado em geral - desvinculando-se da pessoa do empresário. [...] a análise dos interesses objetivos dos credores passa por uma apreciação da situação econômica da empresa e de suas possibilidades de superar a crise de 
liquidez em que se encontra (COMPARATO, 1970, p. 102-103) $)^{11}$

Como bem observa Machado (2005), os problemas estabelecidos pela autonomia da execução fiscal são de tal ordem que "melhor teria sido colocar tais execuções no Juízo Universal da Falência [...]. Mantida como está, a autonomia do processo de execução fiscal faz-se praticamente impossível à administração adequada de tais problemas.” (MACHADO, 2005, p. 702). Dessa forma, sustenta o autor que a competência para a apreciação das questões atinentes aos créditos tributários suscitadas em embargos não seria alterada, continuando a ser apreciadas no Juízo privativo dos feitos da Fazenda. Somente após o julgamento dos eventuais embargos é que a competência para o processamento da execução seria deslocada para o Juízo universal da falência (MACHADO, 2005, p. 702). ${ }^{12}$ Para Lopes (2008, p. 125):

Assim, há a necessidade de se instituir um verdadeiro Juízo Universal da falência, amplo o suficiente para atrair a competência, inclusive, das execuções da natureza fiscal. Referida providência é salutar para resguardar a correta observância da ordem de preferência dos créditos tributários instituídos pelo artigo 83 da Lei n. ${ }^{\circ} 11.101 / 2005$.

${ }^{11}$ Sobre tal ponderação, acrescente-se que, quanto menores forem os custos de transação, em maior quantidade, serão as relações contratuais para organização dos fatores (capital, trabalho, terra e tecnologia). Como se nota, considerando-se o aspecto dinâmico da empresa, esta é um feixe coordenado de relações jurídicas estabelecidas por contratos. Diante disso, por uma abordagem econômica, a eficiência consiste em diminuir ao máximo os custos de transação, para que, cada vez mais, sejam celebrados contratos e, cada vez mais, haja organização, acúmulo dos fatores de produção, resultando em maximização de riquezas, representadas pelo lucro. Nesse sentido, "O direito é, então, um importante elemento na conformação da sociedade e sua orientação à maximização da riqueza e otimização de sua distribuição. Analisar o Direito conforme critérios e métodos econômicos nada mais é do que procurar elaborá-lo, interpretá-lo e aplicá-lo de modo a alcançar a eficiência econômica, entendida esta como a maximização na geração e distribuição dos recursos materiais disponíveis em uma dada comunidade [...] Assim, a análise e aplicação do Direito de forma economicamente eficiente (ou seja, com o objetivo de maximização da riqueza) é não apenas possível, mas é também uma exigência da Constituição Federa de 1988, que a elevou, como se vê, à posição de um dos objetivos fundamentais da República." (PIMENTA, 2006, p. 24-25).

${ }^{12}$ Quanto à autonomia da execução fiscal, o Superior Tribunal de Justiça, por meio da Segunda Seção, passou a entender que os atos que resultem em constrição do patrimônio da empresa recuperanda ficam sujeitos ao juízo da recuperação, sob pena de frustrar esse procedimento que objetiva devolver à sociedade comercial as condições para voltar a desempenhar suas atividades, conforme AgRg no CC 124052/SP,Rel. Min. João Otávio de Noronha, Segunda Seção, julgado em 22/10/2014, DJE 18/11/2014. Não se trata de posicionamento unânime, havendo manifestações em sentido contrário. A Primeira Seção, por exemplo, entendeu, no AgRg em Conflito de Competência 112.646/DF, expressamente pela inaplicabilidade dos precedentes da Segunda Seção, de forma que, a menos que o crédito tributário seja extinto ou tenha a exigibilidade suspensa, a execução fiscal terá seu regular processamento, mantendo-se plenamente respeitadas as faculdades e liberdade de atuação do juízo por ela responsável, conforme AgRg no CC 112.646/DF, Rel. Ministro Herman Benjamin, Primeira Seção, julgado em 11/05/2011, DJe 17/05/2011 (BRASIL, 2016). 
Para Guimarães (2007b, p. 275):

Como antes assinalado, a execução dos créditos tributários não está sujeita à recuperação judicial, nos termos do parágrafo $7^{\circ}$, do art. $6^{\circ}$, da nova Lei, cabendo às Fazendas Públicas e ao Instituto Nacional do Seguro Social - INSS deferirem, nos termos da legislação específica, parcelamento dos créditos, em sede de recuperação judicial, como dispõe o art. 68. É lamentável que o novo instituto da recuperação, de tanta relevância social, possa não ter incluído os créditos tributários dentre aqueles sujeitos à sua jurisdição. Como solucionar a situação de uma empresa em crise se o seu passivo fiscal fica à margem do processo? Sabidamente, quando o empresário encontra-se em dificuldades financeiras, são exatamente os tributos e encargos financeiros aqueles que primeiro deixam de ser pagos ou recolhidos. Pretender resolver a crise da empresa sem que a Fazenda Pública possa dar a sua contribuição é um retrocesso. Se a empresa tem uma função social a ser preservada, o Estado deve ser o primeiro interessado na manutenção da atividade produtiva, na manutenção dos empregos e no aumento da arrecadação. É inconcebível que o Fisco, além de não contribuir para a recuperação, frise-se, coloque em risco o salvamento da empresa, caso o parcelamento, conforme previsto no art. 68, não seja deferido. Tal postura não se coaduna com o Estado moderno voltado para os interesses sociais.

\section{Écio Perin Júnior se manifesta (2005, p. 239):}

[...] Mencionado dispositivo, ao exigir esta certidão, sem que até o momento a devida legislação tenha admitido o parcelamento de dívida tributária, inviabiliza a recuperação e, o que é pior, acaba por ferir o princípio do par conditio creditorum, pois o fato de a empresa ter de apresentar a certidão negativa, vale dizer, a prova de que quitou seus débitos tributários, está em flagrante sobreposição à ordem hierárquica dos créditos previstos em Lei.

\section{Para Barbosa (2005, p. 731):}

Em face da elevada carga tributária, sabemos que, via de regra, o principal problema das empresas brasileiras que se encontram em dificuldade financeira está relacionado ao pagamento dos tributos. Na maioria das vezes, deixa-se de pagar os tributos para se honrar os compromissos com fornecedores e salários dos empregados. Ou seja, o principal credor dessas empresas é o governo (federal, estadual e/ou municipal). Ocorre que as regras da recuperação judicial, que propiciam ampla negociação com os credores, não envolvem a participação do Estado, mas tão somente credores privados. Isto pode pôr em risco a aplicação e funcionamento desse novo instituto, especialmente porque tanto a nova lei de recuperação de empresas (artigo 57) quanto o CTN (artigo 191-A) exigem a apresentação de prova da quitação de todos os tributos para a concessão da recuperação judicial.

Para Bezerra Filho (2005, p. 175):

O objetivo do legislador nesse dispositivo é o de obrigar o devedor a quitar 
suas dívidas fiscais antes do ajuizamento da recuperação judicial ou, ao menos, providenciar o seu parcelamento, nos termos da legislação tributária aplicável. Note-se, no entanto, que isso pode inviabilizar a recuperação de inúmeras empresas em situação de crise econômico - financeira, na medida em que, na maioria das vezes, os encargos fiscais, ao lado das dívidas com financiamento bancário, são os maiores responsáveis pela própria crise em que a empresa de encontra.

Nas palavras de Munhoz (2006, p. 280-281):

A exemplo do regime anterior, a Lei atual deixou de fora do processo de falência e de recuperação os débitos tributários. Não obstante, por força do artigo 57, a concessão da recuperação fica a depender necessariamente da anuência das autoridades tributárias, na medida em que não se poderá reorganizar a empresa que não apresentar certidões negativas de débitos tributários, ainda que o plano tenha sido aprovado pelos demais credores. Por esta razão, para a completude do sistema de reorganização da empresa, é fundamental que a Lei de recuperação seja secundada pela Lei tributária, na medida em que cabe a esta estabelecer as condições especiais de parcelamento dos débitos de tributos para efeito de recuperação, conforme prescreve o artigo 68. Diante desse quadro, considerando as formas de parcelamento de débitos tributários atualmente em vigor, a regra constante no artigo 57, ora examinado, pode levar à completa inviabilização da recuperação da empresa. A análise econômica brasileira demonstra que as empresas em crise financeira normalmente apresentam dívidas tributárias vultosas, sendo as obrigações tributárias, normalmente, as que em primeiro lugar deixam de ser pagas pelo devedor. Isso se explica em virtude do menor poder de constrangimento à atividade do devedor detido pelo fisco comparativamente aos demais credores. A falta de pagamento de tributos não gera para o devedor o risco de ser pedida sua falência, não leva ao risco de descontinuidade da atividade, como ocorre, por exemplo, no caso de falta de pagamentos devidos a fornecedores (matérias primas e insumos) ou aos empregados (greve), contando o devedor, ainda, com a ineficiência e morosidade do sistema fiscal de cobrança.

O artigo 57 da Lei 11.101/05 prevê que, após a juntada aos autos do plano de recuperação aprovado em assembleia ou após decorrido o prazo previsto no artigo 55 da Lei 11.101/05, sem que tenha sido oposta objeção ao plano, o devedor terá, então, que apresentar em cinco dias as certidões negativas de débitos tributários, conforme imposto pelos artigos $151^{13}, 205^{14}$ e $206^{15}$ do Código Tributário Nacional Brasileiro (CTN).

13 "Art. 151. Suspendem a exigibilidade do crédito tributário: I - moratória; II - o depósito do seu montante integral; III - as reclamações e os recursos, nos termos das leis reguladoras do processo tributário administrativo; IV - a concessão de medida liminar em mandado de segurança. V - a concessão de medida liminar ou de tutela antecipada, em outras espécies de ação judicial; VI - o parcelamento." (BRASIL, 1966, online).

14“Art. 205. A lei poderá exigir que a prova da quitação de determinado tributo, quando exigivel, seja feita por certidão negativa, expedida à vista de requerimento do interessado, que contenha todas as informações necessárias à identificação de sua pessoa, domicílio fiscal e ramo de negócio ou atividade e indique o período a que se refere o pedido. Parágrafo único. A certidão negativa será sempre expedida 
A priori, parece que o legislador conferiu prazo para que o devedor providencie a quitação das dívidas tributárias, concomitantemente com a elaboração do plano de recuperação judicial. Referido prazo inicia-se com o deferimento da recuperação judicial e termina com a juntada aos autos do plano de recuperação judicial, devidamente aprovado pela assembleia geral de credores, ou após decorrido o prazo para a instalação da assembleia geral de credores, a fim de deliberar sobre eventual objeção formulada pelos credores ao plano de recuperação. O prazo para instalação da assembleia é de 150 dias, contados do deferimento do processamento da recuperação judicial. Observase que a exiguidade do prazo acaba por inviabilizar a quitação dos tributos eventualmente devidos pela empresa em recuperação, e, caso seja realmente essa a intenção do legislador, tal fato comprometerá os objetivos da recuperação de empresas instituídos pela novel legislação (LOPES, 2008, p. 208).

Leva-se à reflexão:

a) se a recuperação judicial não interfere no crédito tributário, (pois o deferimento do processamento da recuperação judicial não suspende o curso das execuções fiscais, conforme artigo $6^{\circ}$, parágrafo $7^{\circ}$, da Lei $\left.11.101 / 05\right)$ e, se;

b) o plano de recuperação não poderá incluir o crédito tributário (conforme artigo $187^{16}$ do CTN, que excepciona a regra contida no artigo $49^{17}$ da Lei 11.101/05, por outro lado, poder-se-ia pensar, de maneira simplista, superficial e equivocada, que o crédito tributário não interferiria, então, no processo de recuperação judicial, já que:

- a decisão que defere o processamento da recuperação judicial dispensa o devedor de apresentar certidões negativas para o exercício da sua atividade econômica, exceto para a contratação com o poder público (conforme artigo 52, II $^{18}$, da Lei 11.101/05) e;

- o credor tributário não participa da assembleia geral de credores (conforme artigo 41 da Lei 11.101/05), destinada à aprovação, modificação ou rejeição

nos termos em que tenha sido requerida e será fornecida dentro de 10 (dez) dias da data da entrada do requerimento na repartição." (BRASIL, 1966, online).

15“Art. 206. Tem os mesmos efeitos previstos no artigo anterior a certidão de que conste a existência de créditos não vencidos, em curso de cobrança executiva em que tenha sido efetivada a penhora, ou cuja exigibilidade esteja suspensa." (BRASIL, 1966, online).

16“Art. 187. A cobrança judicial do crédito tributário não é sujeita a concurso de credores ou habilitação em falência, recuperação judicial, concordata, inventário ou arrolamento." (BRASIL, 1966, online).

17 “Art. 49. Estão sujeitos à recuperação judicial todos os créditos existentes na data do pedido, ainda que não vencidos." (BRASIL, 2005, online).

18“Art. 52. Estando em termos a documentação exigida no art. 51 desta Lei, o juiz deferirá o processamento da recuperação judicial e, no mesmo ato: II - determinará a dispensa da apresentação de certidões negativas para que o devedor exerça suas atividades, exceto para contratação com o Poder Público ou para recebimento de benefícios ou incentivos fiscais ou creditícios, observando o disposto no art. 69 desta Lei." (BRASIL, 2005, online).

$50 \bullet \quad$ R. Opin. Jur., Fortaleza, ano 19, n. 31, p.33-74, maio/ago. 2021 
o plano. ${ }^{19}$

Todavia, ocorre que a recuperação judicial de empresas, ao tratar de uma diversidade de mecanismos relacionados à superação da crise econômica e financeira da empresa, que se relacionam com a atividade desenvolvida pelo empresário, interfere na formação patrimonial do empresário e, ao menos indiretamente, no interesse do Fisco. Isso, pois, caso o plano de recuperação judicial aborde a alienação das unidades produtivas isoladas e se for aprovado pelos credores reunidos em assembleia, o patrimônio utilizado na empresa sofrerá alteração, na medida em que for sendo transferido onerosamente a terceiros o estabelecimento empresarial ${ }^{20}$, em relação ao

${ }^{19}$ Esta interpretação literal, na jurisprudência atual, possui o seguinte sentido: "TRIBUTÁRIO. ADMINISTRATIVO. EXIGÊNCIA DE APRESENTAÇÃO DE CERTIDÃO NEGATIVA DE DÉBITO. IMPOSSIBILIDADE. SOCIEDADE EM RECUPERAÇÃO JUDICIAL. 1. Hipótese em que o Tribunal local decidiu que, no caso dos autos, a empresa em Recuperação Judicial estava dispensada de apresentar certidões negativas, inclusive para contratação com Poder Público. 2. O STJ vem entendendo ser inexigivel, pelo menos por enquanto, qualquer demonstração de regularidade fiscal para as empresas em recuperação judicial, seja para continuar no exercício de sua atividade (já dispensado pela norma), seja para contratar ou continuar executando contrato com o Poder Público. Nos feitos que contam como parte pessoas jurídicas em processo de recuperação judicial, a jurisprudência do STJ tem-se orientado no sentido de se viabilizarem procedimentos aptos a auxiliar a empresa nessa fase. Nesse sentido: REsp 1.173.735/RN, Ministro Luis Felipe Salomão, Quarta Turma, DJe 9.5.2014; AgRg na MC 23.499/RS, Rel. Ministro Humberto Martins, Rel. p/ Acórdão Ministro Mauro Campbell Marques, Segunda Turma, DJe 19.12.2014. 3. Registro que o novo regime trazido pela Lei 13.043/2014, que instituiu o parcelamento específico para débitos de empresas em recuperação judicial, não foi analisado no acórdão a quo, uma vez que foi proferido em data anterior à vigência do mencionado normativo legal. 4. Agravo Regimental não provido." (STJ. AgRg no AREsp 709.719/RJ, Rel. Ministro HERMAN BENJAMIN, SEGUNDA TURMA, julgado em 13/10/2015, DJe 12/02/2016) (BRASIL, 2016, online, grifo nosso).

20 "Para o exercício do comércio, mesmo rudimentar e modesto, três coisas são necessárias ao comerciante: capital, trabalho e organização. Ao conjunto dessas coisas que servem ao comerciante para a prática de sua profissão é o que se denomina estabelecimento comercial. É o negócio, a casa do comércio, realidade concreta que todo mundo conhece, que sempre existiu, mas cuja noção jurídica só modernamente passou a ser objeto de cogitação e de especulação dos juristas. Estabelecimento comercial não é apenas a casa, o local, o cômodo, no qual o comerciante exerce sua atividade, mas é o conjunto, o "complexo das várias forças econômicas e dos meios de trabalho que o comerciante consagra ao exercício do comércio, impondo-lhes uma unidade formal, em relação com a unidade do fim”, para o qual ele as reuniu e organizou. Esse conjunto constitui, como lembra Carvalho de Mendonça, o organismo econômico aparelhado para o exercício do comércio. É o instrumento, a máquina de trabalho do comerciante." (BORGES, 1968, p. 182) "Toda pessoa (física ou jurídica) que pratica determinada atividade profissional necessita, direta ou indiretamente, de um conjunto de bens constituintes, em ultima análise, de suas "ferramentas de trabalho". Assim, o é também quando tratamos dos empresários, sujeitos de direito praticantes de atividade voltada para a produção e/ou circulação de bens ou serviços com intuito lucrativo. Todo empresário (sujeito de direito) necessita de um conjunto patrimonial a ser por ele utilizado no exercício de sua atividade profissional (empresa) [...] Estes três elementos (empresa empresário - estabelecimento) estão intrínseca e necessariamente interligados. Não existe atividade (empresa) sem um sujeito de direito (empresário) que a pratique em seu próprio nome e se valha, para isso, de um conjunto de bens por ele organizado (estabelecimento). [...]. Assim, é possível afirmar que todo empresário dispõe de um estabelecimento, o qual é por ele empregado no exercício de sua atividade profissional, cuja importância econômica varia enormemente conforme a amplitude de 
qual estão os bens que integram o acervo patrimonial do devedor de tributos. Ou seja, considerando-se que o devedor responde com todos os seus bens, presentes e futuros, pela satisfação do crédito exigido, nos termos da lei processual brasileira, os atos de alienação de bens do devedor alteram a própria garantia patrimonial do crédito tributário.

Sabe-se que os atos de disposição patrimonial, se forem praticados fora do processo de recuperação judicial, podem ser, nos termos da lei, considerados nulos e/ou ineficazes quanto ao credor fiscal. Mas, se porém, se praticados como forma de cumprimento do plano aprovado pelos credores, que foi homologado judicialmente, tais atos de disposição terão validade e eficácia junto ao credor tributário. Isso se dá, por exemplo, nas hipóteses de alienação de unidades produtivas isoladas, em cumprimento do plano de recuperação judicial aprovado e judicialmente homologado.

A rigor, a venda do estabelecimento empresarial enseja a sucessão do adquirente no passivo tributário correspondente ao estabelecimento alienado, nos termos do artigo $133^{21}$ do CTN. No entanto, se a alienação do estabelecimento se der em processo de recuperação judicial, a regra de sucessão não será aplicada, conforme o parágrafo $1^{\circ}$ do mesmo artigo 133 do Código Tributário Nacional. Logo, poderá ser vendido ativo integrante do patrimônio do devedor, mediante condições estabelecidas no plano de recuperação, sem que o credor de tributos interfira ou mesmo participe da deliberação

empresa exercida. (PIMENTA, 2004, p. 99). Considerando-se que a empresa é justamente a atividade exercida pelo empresário, esta fica patrimonialmente evidenciada pelo estabelecimento, o qual representa a junção dos bens necessários ao exercício da atividade econômica. $O$ estabelecimento também é chamado de Fundo de Comércio pelos Franceses e Azienda pelos Italianos. "No direito romano, as expressões negotium, mensa, merx, ou merx peculiaris, taberna, mercatura, negotiatio correspondiam ao estabelecimento, negócio ou casa comercial. No francês, fonds de commerce, Maison de commerce, établissemente commercial; no italiano, azienda, fondo, fondaco; no espanhol, havienda, empresa; no anglo americano, goodwill, business, no holandês, Zaak, Handelaszaak; no alemão, Geschaft, Handelsgeschaft, Haus, Handlung, Unternehmen, etc. Por influência do francês, introduziu-se entre nós, como sinônimo de estabelecimento comercial, a expressão fundo de comércio." (BORGES, 1968, p. 183). "Se a empresa é a atividade exercida pelo empresário, a sua representação patrimonial é denominada estabelecimento, que é a reunião de todos os bens necessários para a realização da atividade empresarial, também chamada de fundo de comércio, sob a influência dos franceses ou azienda para os Italianos. Esses bens, que, em seu conjunto, acabam ganhando um sobre valor, na medida em que a reunião deles acaba por produzir a riqueza explorada pelo empresário, podem ser materiais ou imateriais (BERTOLDI; RIBEIRO, 2006, p. 54).

21“Art. 133. A pessoa natural ou jurídica de direito privado que adquirir de outra, por qualquer título, fundo de comércio ou estabelecimento comercial, industrial ou profissional, e continuar a respectiva exploração, sob a mesma ou outra razão social ou sob firma ou nome individual, responde pelos tributos, relativos ao fundo ou estabelecimento adquirido, devidos até à data do ato: I - integralmente, se o alienante cessar a exploração do comércio, indústria ou atividade; II - subsidiariamente com o alienante, se este prosseguir na exploração ou iniciar dentro de seis meses a contar da data da alienação, nova atividade no mesmo ou em outro ramo de comércio, indústria ou profissão. $\S 1$ o $O$ disposto no caput deste artigo não se aplica na hipótese de alienação judicial: I - em processo de falência; II - de filial ou unidade produtiva isolada, em processo de recuperação judicial.” (BRASIL, 1966, online). 
sobre a alienação, sobre as condições da alienação, e sem que lhe seja dada qualquer garantia da sucessão do passivo tributário por trespasse.

\section{A PROBLEMÁTICA EXIGÊNCIA DE CERTIDÕES}

Viu-se que impõe o artigo 57 da Lei 11.101/05 que o devedor em recuperação, após a aprovação do plano em assembleia de credores ou, após o decurso do prazo do artigo 55 sem objeções ao plano, junte nos autos certidão negativa de débito tributário como ato e requisito anterior à homologação judicial do plano. Com tal previsão, ao que parece, busca-se assegurar que os atos de disposição patrimonial praticados em cumprimento ao plano de recuperação judicial não interfiram na satisfação do crédito tributário, já que este, nos termos da certidão negativa de débito, já teria sido, em tese, satisfeito.

Assim, como requisito de concessão da recuperação judicial de empresas, dispõe o art. 191-A do CTN (BRASIL, 1966, online), incluído pela Lei Complementar 118/2008, que: “A concessão de recuperação judicial depende da apresentação da prova de quitação de todos os tributos, observado o disposto nos artigos 151, 205 e 206 desta Lei." Ocorre que os empresários em situação de crise econômica e financeira podem ter passivos tributários que não se tenha condições de arcar de pronto, para auferir a certidão negativa de débito. ${ }^{22}$ Já o artigo $68^{23}$ da Lei $11.101 / 05$ prevê que as Fazendas

${ }^{22}$ A doutrina especializada que trata do tema da recuperação judicial e falências é, majoritariamente, no sentido de que a exigência das certidões negativas contraria o próprio instituto. Destaque-se: Miretti (2005, p. 275), Comentários à Nova Lei de Falências e Recuperação de Empresas, Mandel (2005, p. 129), Nova Lei de Falências e Recuperação de Empresas Anotada e Silva (2005, p. 63) Recuperação Judicial de Empresas. A esse respeito tem-se ainda, a lição de Bezerra Filho (2005, p. 168) Nova Lei de Recuperação e Falências Comentada: "Aliás, neste ponto, a Lei não aproveitou o ensinamento que os 60 anos de vigência do Dec-lei 7.661/45 trouxeram, a partir do exame do art. 174 daquela lei. Este artigo exigia que, para que a concordata fosse julgada cumprida, o devedor apresentasse comprovação de que havia pago todos os impostos, sob pena de falência. Tal disposição, de praticamente impossível cumprimento, redundou na criação jurisprudencial que admitia o pedido de desistência da concordata, embora sem expressa previsão legal. E a jurisprudência assim se firmou, porque exigir o cumprimento daquele art. 174 seria levar a empresa, certamente, à falência. Sem embargo de tudo isso, este art. 57, acoplado ao art. 49, repete o erro de trazer obrigações de impossível cumprimento para sociedades empresárias em crise."

Bem por isso, mostra-se a orientação que vem se formando pela desnecessidade da demonstração da regularidade fiscal, tendo a Vasp apresentado precedentes, uma da 1a Vara Cível de Ponta Grossa (recuperação judicial da empresa Wosgrau Participações Indústria e Comércio Ltda., Proc. N. 390/2005, MM. Juiz Luiz Henrique Miranda, j. 2/12/2005) e outra da 8a Vara Empresarial do Rio de Janeiro (recuperação judicial da Varig S/A Viação Aérea Riograndense, MM. Juiz Luiz Roberto Ayoub, j. 28/12/2005), além da própria Parmalat Brasil S/A - Indústria de Alimentos, entre outros. Pelo viés econômico, se vê por Marcos de Barros Lisboa, Secretário de Política Econômica do Ministério da Fazenda, que "o Fisco colabora com a recuperação da empresa mediante o parcelamento dos créditos tributários", fixando norma determinando "que as Receitas de cada ente federativo criem regras 
Públicas e o Instituto Nacional do Seguro Social - INSS poderão deferir, nos termos da legislação específica, parcelamentos de seus créditos, em sede de recuperação judicial, de acordo com os parâmetros estabelecidos na Lei no 5.172, de 25 de outubro de 1966, que é o Código Tributário Nacional Brasileiro. Com esse parcelamento, seria suspensa a exigibilidade do crédito tributário, conforme art. 151, VI, do Código Tributário Nacional, ao mesmo tempo em que se estabeleceriam os termos e as garantias de seu cumprimento, conforme estabelecido em lei específica, prevista no artigo $155-\mathrm{A}^{24}$, caput, do Código Tributário Nacional.

Ao que se nota, considerando-se que o instituto da recuperação judicial de empresas tem por objetivo viabilizar a superação da situação de crise econômicofinanceira do devedor, a fim de permitir a manutenção da fonte produtora, do emprego dos trabalhadores e dos interesses dos credores, promovendo, assim, a preservação da empresa, sua função social e o estímulo à atividade econômica, entendeu o legislador que, certas vezes, inclusive o parcelamento do crédito tributário, nos termos de Lei específica, poderia inviabilizar que o plano de recuperação judicial aprovado atingisse seu objetivo, de forma eficiente.

Nesse contexto, na data em que foi promulgada a Lei 11.101/05, publicou-se também a Lei Complementar 118, que modificou algumas normas contidas no Código Tributário Nacional, acrescendo o parágrafo 3o no artigo 155-A do CTN, para prever que "Lei específica disporá sobre as condições de parcelamento dos créditos tributários do devedor em recuperação judicial." 25

específicas sobre o parcelamento de dívidas tributárias para empresas em recuperação de empresas", como forma de ajudar a recuperação judicial, já que dela não participa, "estabelecendo uma dilatação dos prazos para pagamento, aliviando as necessidades de fluxo de caixa da empresa e propiciando a regularização de sua situação fiscal." (LISBOA, 2005, p. 52).

23"Art. 68. As Fazendas Públicas e o Instituto Nacional do Seguro Social - INSS poderão deferir, nos termos da legislação específica, parcelamento de seus créditos, em sede de recuperação judicial, de acordo com os parâmetros estabelecidos na Lei no 5.172, de 25 de outubro de 1966 - Código Tributário Nacional." (BRASIL, 2005, online).

24“Art. 155-A. O parcelamento será concedido na forma e condição estabelecidas em lei específica. § 1o Salvo disposição de lei em contrário, o parcelamento do crédito tributário não exclui a incidência de juros e multas. $\S 2^{\circ}$ Aplicam-se, subsidiariamente, ao parcelamento as disposições desta Lei, relativas à moratória. $\S 3^{\circ}$ Lei específica disporá sobre as condições de parcelamento dos créditos tributários do devedor em recuperação judicial. $\S 4^{\circ} \mathrm{A}$ inexistência da lei específica a que se refere o $\S 3^{\circ}$ deste artigo importa na aplicação das leis gerais de parcelamento do ente da Federação ao devedor em recuperação judicial, não podendo, neste caso, ser o prazo de parcelamento inferior ao concedido pela lei federal específica." (BRASIL, 1966, online).

${ }^{25}$ Várias foram as iniciativas para tratar sobre as condições de parcelamento dos créditos tributários do devedor em recuperação judicial, tais como o PL 6447/2005, de 15/12/2005, de autoria do Deputado Jorge Boeira, que dispõe "sobre parcelamento para empresas em recuperação judicial de débitos com a Secretaria da Receita Federal, a Procuradoria-Geral da Fazenda Nacional e o Instituto Nacional do Seguro Social e dá outras providências". Também o PL 246/2003, 27/02/2003, de autoria do Deputado Paes Landim, que dispõe sobre "parcelamento e pagamento de débitos de tributos, contribuições fiscais

54 R. Opin. Jur., Fortaleza, ano 19, n. 31, p.33-74, maio/ago. 2021 
Os parcelamentos tributários que poderiam ser solicitados pelo devedor em recuperação tinham características que dificultavam sobremaneira ou, até mesmo, inviabilizavam o cumprimento do plano de recuperação aprovado, impedindo a superação da crise econômico e financeira da empresa. Vê-se, então, que o crédito tributário, apesar de que, em tese, não devesse sofrer interferência do plano de recuperação judicial, bem como, em tese, não interferir no cumprimento do plano judicial, acaba por interferir, nos termos literais da lei. ${ }^{26}$

e previdenciárias. " No mesmo sentido, tais Projetos foram apensados ao PL 5250/2005, apresentado em 17/05/2005, pelo Senador Fernando Bezerra, que dispõe "sobre o parcelamento de débitos de devedores em recuperação judicial, em face da União, autarquias, fundações públicas e o Fundo de Garantia do Tempo de Serviço, além de alterar os artigos. 57 e 73 da Lei no 11.101/05.” Também foram apresentados Projetos de Lei que almejavam revogar a exigência contida no artigo 57 da Lei 11.101/05, tais como o PL 6028/2005, de 6/10/2005, de autoria do Deputado Jorge Boeira, que "Revoga o art. 57 da Lei no 11.101/05, que "Regula a recuperação judicial, extrajudicial e a falência do empresário e da sociedade empresária”, para dispensar a exigência de apresentação de certidões negativas de débitos tributários na instrução do requerimento de recuperação judicial”. Da mesma forma, o PL 7363/2006, de 7/12/2006, de autoria do Deputado Luiz Piauhylino, que "Revoga o art. 57 da Lei $n^{\circ}$ 11.101/05, para eliminar a exigência de apresentação prévia de certidão negativa no processo de recuperação judicial". O PL 7363/2006 foi apensado, em 15/12/2006, ao PL 6028/2005. Este, por sua vez, foi apensado, em 20/10/2005, ao PL 5250/2005.

${ }^{26}$ A jurisprudência brasileira tem cuidado de limitar os efeitos da previsão contida no $\S 77^{\circ}$ do art. $6^{\circ}$, dando-lhe interpretação de acordo com os fins da recuperação judicial previstos no artigo 47 da Lei 11.101/05, de forma a vedar a prática de atos judiciais que comprometam o patrimônio da empresa em recuperação. Não obstante a previsão contida no art. $6^{\circ}$, § 7º, da Lei n. 11.101/2005 configure prejuízo ao processo de recuperação judicial, a jurisprudência tem limitado a sua aplicação, com a finalidade de possibilitar o reerguimento da empresa em dificuldades. Veja-se: AGRAVO NO CONFLITO DE COMPETÊNCIA. JUÍZO DA EXECUÇÃO FISCAL E JUÍZO DA RECUPERAÇÃO JUDICIAL. COMPETÊNCIA DO JUÍZO FALIMENTAR PARA TODOS OS ATOS QUEE IMPLIQUEM RESTRIÇÃO PATRIMONIAL. 1. As execuções fiscais ajuizadas em face da empresa em recuperação judicial não se suspenderão em virtude do deferimento do processamento da recuperação judicial, ou seja, a concessão da recuperação judicial para a empresa em crise econômico-financeira não tem qualquer influência na cobrança judicial dos tributos por ela devidos. 2. Embora a execução fiscal, em si, não se suspenda, são vedados atos judiciais que reduzam o patrimônio da empresa em recuperação judicial, enquanto for mantida essa condição. Isso porque a interpretação literal do art. $6^{\circ}$, $\S 7{ }^{\circ}$, da Lei 11.101/05 inibiria o cumprimento do plano de recuperação judicial previamente aprovado e homologado, tendo em vista o prosseguimento dos atos de constrição do patrimônio da empresa em dificuldades financeiras. 3. Agravo não provido. (STJ. AgRg no AgRg no CC 119.970/RS, Rel. Ministra NANCY ANDRIGHI, SEGUNDA SEÇÃO, julgado em 28/08/2013, DJe 17/09/2013); TRIBUTÁRIO. AGRAVO REGIMENTAL EM RECURSO ESPECIAL. EXECUCÃO FISCAL. EMPRESA COM FALÊNCIA DECRETADA. FUNCIONAMENTO PARCIAL. OBRIGAÇÕES CONTRATUAIS A SEREM ADIMPLIDAS. PENHORA E ALIENAÇÃO DE BENS DA MASSA FALIDA PARA SATISFAZER O EXECUTIVO FISCAL. INVIABILIDADE. ART. 5, DA LINDB. ATO DESASTROSO PARA A PRODUÇÃO E CONTINUIDADE DO EMPREENDIMENTO. PRINCÍPIO DA PRESERVAÇÃO DA EMPRESA. PRECEDENTES DO STJ. QUITAÇÃO DO CRÉDITO TRIBUTÁRIO EM MOMENTO POSTERIOR. POSSIBILIDADE. AGRAVO NÃO PROVIDO. 1. No caso, seria desastroso o desfazimento de bens pertencentes à massa para atender, desde já, o desejo de continuidade do executivo fiscal da Fazenda, porque sabotaria a tentativa da massa de honrar as avenças firmadas, arruinando, em definitivo, a viabilidade que restou do organismo 


\section{REFLEXÕES SOBRE O PARCELAMENTO COMO CONDIÇÃO PARA APROVAÇÃO DO PLANO DE RECUPERAÇÃO: APARENTE INEFICIÊNCIA}

Durante muitos anos, não foi publicada a legislação específica acerca do parcelamento dos créditos tributários do devedor em recuperação judicial. Por isso, chegaram às cortes brasileiras situações nas quais empresas que e encontravam em crise econômico e financeira aprovaram seu plano de recuperação judicial perante os seus credores sujeitos à recuperação judicial, mas sem que conseguissem parcelar o crédito tributário em conformidade com o parcelamento especial para empresas em recuperação judicial. ${ }^{27}$ Como exemplo de tais notáveis situações, houve:

empresarial. Aplicação da interpretação teleológica. 2. "Apesar de a execução fiscal não se suspender em face do deferimento do pedido de recuperação judicial (art. 6º, § 7º, da LF n. 11.101/05, art. 187 do CTN e art. 29 da LF n. 6.830/80), submetem-se ao crivo do juízo universal os atos de alienação voltados contra o patrimônio social das sociedades empresárias em recuperação, em homenagem ao princípio da preservação da empresa" (CC 114.987/SP, Rel. Min. PAULO DE TARSO SANSEVERINO, Segunda Seção, DJe 23/3/2011). 3. Ausência de prejuízo à Fazenda Pública, uma vez que o pagamento do crédito tributário devido será assegurado pelo juízo falimentar no momento oportuno, observadas as preferências legais. 4. Agravo regimental não provido. (STJ. AgRg no REsp 1121762/SC, Rel. Ministro ARNALDO ESTEVES LIMA, PRIMEIRA TURMA, julgado em 05/06/2012, DJe 13/06/2012) PROCESSUAL CIVIL. AGRAVO REGIMENTAL. CONFLITO DE COMPETÊNCIA. EXECUÇÃO NO ÂMBITO TRABALHISTA. NATUREZA FISCAL. DEFERIMENTO DA RECUPERAC̣ÃO JUDICIAL. ART. $6^{\circ}$, § 7 , DA LEI No 11.101/05, COM A RESSALVA NELE PREVISTA. PRÁTICA DE ATOS QUE COMPROMETAM O PATRIMÔNIO DO DEVEDOR OU EXCLUAM PARTE DELE DO PROCESSO DE RECUPERAÇÃO JUDICIAL. IMPOSSIBILIDADE. POSSIBILIDADE DE PARCELAMENTO. INEXISTÊNCIA DE VIOLAÇÃO DO ART. 97 DA CF E DE DESRESPEITO À SÚMULA VINCULANTE N. 10/STF. 1. O fato de a execução fiscal em trâmite na Justiça trabalhista se dirigir contra empresa em recuperação judicial atrai para a Segunda Seção a competência para processar e julgar o conflito de competência, a teor do que preconiza o art. $9^{\circ}, 2^{\circ}$, IX, do RISTJ. Precedentes. 2. Inexistência de violação do art. 97 da CF e de desrespeito à Súmula Vinculante n. 10/STF, pois a decisão agravada, em juízo perfunctório próprio dos provimentos liminares, apenas realizou uma interpretação sistemática dos dispositivos legais aplicáveis ao caso concreto. 3. O deferimento da recuperação judicial não suspende a execução fiscal, porém não é permitido ao Juízo no qual essa se processa a prática de atos que comprometam o patrimônio do devedor ou excluam parte dele do processo de recuperação judicial. 4. Caso a execução fiscal prossiga, a empresa em recuperação não poderá se valer de importante incentivo da lei, qual seja, o parcelamento, modalidade que suspende a exigibilidade do crédito tributário (art. 151, I do CTN). 5. O artigo 187 do CTN trata da preferência da execução fiscal sobre outros créditos habilitados e inexiste ofensa a esse dispositivo ante a concessão do parcelamento fiscal, visto que o crédito continua com seus privilégios, mas passa a ser recolhido de maneira diferida, justamente para se garantir à empresa em situação de re regimental não provido. (STJ. AgRg no CC 120.407/SP, Rel. Ministro LUIS FELIPE SALOMÃO, SEGUNDA SEÇÃO, julgado em 27/06/2012, DJe 01/08/2012) (BRASIL, 2016).

${ }^{27} \mathrm{O}$ Superior Tribunal de Justiça, no Recurso Especial no 1.187.404/MT, Rel. Min. Luis Felipe Salomão, Corte Especial, julgado em 19/07/2013, DJE 21/08/2013, afastou, de forma unânime, a exigência de apresentação das certidões negativas, autorizando a concessão da recuperação judicial independentemente da apresentação da prova de regularidade fiscal. Tal posicionamento encontrou justificativa na demora do legislador em cumprir o disposto no art. 155-A, § $3^{\circ}$, do CTN, isto é, na 
a) a recuperação da Varig, que tramitou no Rio de Janeiro, em que o Juiz Luiz Roberto Ayub consignou que a ausência de Lei especial disciplinadora do parcelamento de créditos tributários de quem esteja em processo de recuperação exige tratamento que for mais benéfico ao contribuinte, sendo inaplicável a norma do artigo 191-A do CTN, enquanto não se dê cumprimento ao disposto no artigo 155-A daquele diploma legal;

b) a recuperação da Wosgrau, que tramitou em Ponta Grossa, no Estado do Paraná, em que, na decisão prolatada pelo Juiz Luiz Henrique Miranda, consignou-se que a exigência de apresentação de certidões comprobatórias de inexistência de débitos junto ao Fisco e à previdência, feita pelo artigo 57 da Lei 11.101/05, ofenderia o princípio constitucional da razoabilidade e agrediria as garantias constitucionais dos devido processo legal, ao contraditório e à ampla defesa dadas ao contribuinte;

c) a recuperação da Marquet Ltda., de Barueri, em São Paulo, na qual o Juiz Mário Sérgio Leite aduziu que as ações de execução fiscal não estão sobrestadas pela recuperação judicial e, portanto, não há prejuízos para o Fisco, sem falar que nem sequer houve aprovação de Lei especial que trataria das condições de parcelamento dos créditos tributários;

d) a Recuperação judicial da Parmalat, que tramitou na Capital de São Paulo, em que o Juiz Alexandre Alves Lazzarini entendeu a favor da "orientação que vem se formando pela desnecessidade da demonstração da regularidade fiscal. Naquele processo, foram apresentados à época alguns precedentes, um da $1^{\text {a }}$ Vara Cível de Ponta Grossa e outro da 8a Vara Empresarial do Rio de Janeiro, em que foi frisado que o Fisco deve atender o princípio constitucional da proporcionalidade e, também, os princípios estabelecidos no artigo 47 da Lei n. ${ }^{\circ} 11.101 / 2005$, os quais encontram seu amparo no artigo 170 da Constituição Federal;

e) a recuperação da Bombril, que tramitou em São Paulo, na qual o Juiz Caio Marcelo Mendes de Oliveira entendeu que, "enquanto não regulamentado o

inexistência de legislação específica acerca do parcelamento de créditos das Fazendas Públicas e do INSS em sede de recuperação judicial. Consignou-se que o descumprimento da exigência de regularidade fiscal somente poderia ser atribuído, ao menos naquele momento, à ausência de legislação específica que disciplinasse o parcelamento em sede de recuperação judicial, não podendo constituir ônus do contribuinte, enquanto omissa a legislação, a apresentação de certidões de regularidade fiscal para que the seja concedida a recuperação. Afirmou-se que, muito embora o art. 68 da Lei 11.101/2005 possa sugerir que é faculdade da Fazenda Pública e do INSS a concessão do parcelamento da dívida, especialmente diante do uso do verbo "poder", a interpretação que melhor se compatibiliza com a operacionalidade da recuperação judicial é no sentido de que o parcelamento do crédito tributário constitui um direito do contribuinte em recuperação, na forma prevista nos $\S \S 3^{\circ}$ e $4^{\circ}$ do art. 155-A do CTN. 
artigo 68 da Lei Especial, não há como se exigir a juntada de certidões negativas de débito fiscal, como condição para o deferimento da recuperação da empresa.

Entende-se, neste trabalho, que o poder e privilégio concedido ao Fisco, frise-se, nos termos, literais, que está na lei, nos processos de recuperação judicial, é ineficiente. ${ }^{28}$ Isso, pois:

a) não promove incentivos ex ante aos contratos firmados pela devedora em crise;

b) não promove incentivos em relação à atividade econômica como um todo;

c) revela-se sendo mecanismo que vai contra, ao mesmo tempo, os interesses dos credores e também do devedor, o que não contribui para o sucesso do plano de recuperação;

d) ao sujeitar a deliberação dos credores, bem como a decisão judicial de concessão à autoridade administrativa fiscal, afasta-se do princípio da concentração dos atos, que é indispensável à existência de um ambiente com boa coordenação de divergências e que incentive a negociação entre credores;

e) vai contra o princípio da celeridade, diante da notória e notável demora do serviço público em geral, sobretudo dos órgãos federais, os quais, na última década, fizeram centenas de greves e paralisações em sua atuação, mesmo nos serviços essenciais prestados pela Receita Federal, pelos Aeroportos, Cobrança de Dívida Ativa, etc.

Em que pese o concurso de credores ser um instituto de Direito, regido por normas próprias, sua origem tem nítido caráter econômico, sendo necessário que seu operador saiba efetuar um diálogo entre as disciplinas, a fim de permitir que a resolução do problema seja solucionada da forma mais eficiente possível, atentando simultaneamente para os preceitos legais, econômicos e financeiros que giram em torno do tema (LOPES, 2008, p. 50).

Percebe-se que a Lei 11.101/05 acabou por ignorar relevantes lições que se referem ao incentivo que o crédito fiscal poderia representar na recuperação judicial. Johnson (2006, p. 127) salienta:

Existem inúmeras formas pelas quais as questões tributárias exercem um importante papel na dinâmica das negociações. Considerações tributárias podem ser o principal fator em uma estruturação para uma empresa que fosse

\footnotetext{
${ }^{28} \mathrm{~A}$ empresa fica obrigada a buscar o parcelamento, mesmo se não tiver caixa para tanto. Há também a inexplicável previsão do artigo 57, que obriga a empresa em recuperação a apresentar certidões negativas fiscais. O fisco deveria dar a sua contribuição para a recuperação da empresa, abrindo mão de seus privilégios, pois, em tese, a Fazenda/Governo são os maiores interessados na manutenção de uma unidade produtiva e deveriam oferecer uma maior dose de sacrifício para apoiar sua recuperação, e não o contrário (MANDEL, 2005).
}

58 - R. Opin. Jur., Fortaleza, ano 19, n. 31, p.33-74, maio/ago. 2021 
beneficiada pelo tratamento tributário. $\mathrm{O}$ tratamento tributário favorecido no cancelamento ou na reestruturação de dívida pode permitir que credores cancelem mais dívidas ou criem uma estrutura mais adequada à reestruturação do negócio ou à realocação de riscos e riquezas. De forma inversa, um tratamento tributário desfavorável pode ser um meio de inviabilizar ou evitar que a reestruturação aconteça em termos racionais. Em resumo, a legislação tributária pode impactar o cancelamento de dívidas de várias formas, seja mediante cancelamento do direito delas, cancelamento parcial de principal e juros, cancelamento baseado em deságio ou alongamento, cancelamento baseado na venda de ativos com deságio, seja, ainda, cancelamento baseado em uma mudança do perfil da dívida ou conversão em capital.

\section{O mesmo autor ressalta:}

Em estudo comparativo do tratamento tributário mais compreensivo e favorável para débitos cancelados, foi verificado que vários regimes anglo-saxões (por exemplo, Austrália, Reino Unido e Estados Unidos) tendem a ter um tratamento tributário mais compreensivo e favorável para débitos cancelados, fazendo o ambiente de negócios mais propício para reestruturação, enquanto os países estudados regidos pelo sistema de direito civil (por exemplo, França, Alemanha, Japão) possuíam regimes tributários menos favoráveis ao cancelamento de débito, criando assim poucos incentivos em favor da reestruturação. Nos sistemas estudados regidos pelo direito civil, as questões do tratamento tributário não foram tratadas pela Lei em todos, ou as regras tributárias adotadas tornaram difícil obter um tratamento tributário otimizado (JOHNSON, 2006, p. 127).

Entende-se, neste artigo científico, respeitosamente, que as condições de parcelamento que vigoraram por muitos anos não eram eficientes. A previsão era: "Art. 10. Os débitos de qualquer natureza para com a Fazenda Nacional poderão ser parcelados em até sessenta parcelas mensais, a exclusivo critério da autoridade fazendária, na forma e condições previstas nesta Lei." (BRASIL, 2005, online).

As condições atuais para pagamentos dos créditos tributários foram previstas, apenas recentemente, após cerca de 11 anos de vigência da Lei 11.101/05, com a inclusão do artigo 10-A na Lei 10.522/2002, inclusão trazida pela Lei 13.043/2014. Tal dispositivo possibilitou aos empresários em processamento de recuperação judicial o parcelamento dos débitos com a Fazenda Nacional em até 84 parcelas mensais e consecutivas. ${ }^{29}$ Entende-se neste trabalho que a legislação atual não cria incentivos positivos ao contribuinte, com créditos tributários em aberto, que esteja em recuperação, a aderir tal parcelamento, pois:

\footnotetext{
29“Art. 10-A. O empresário ou a sociedade empresária que pleitear ou tiver deferido o processamento da recuperação judicial, nos termos dos arts. 51, 52 e 70 da Lei no 11.101, de 9 de fevereiro de 2005, poderão parcelar seus débitos com a Fazenda Nacional, em 84 (oitenta e quatro) parcelas mensais e consecutivas, calculadas observando-se os seguintes percentuais mínimos, aplicados sobre o valor da dívida consolidada: (Incluído pela Lei no 13.043, de 2014).” (BRASIL, 2005, online).
} 
a) a ampliação de 60 para 84 meses não é significativa, considerando-se inclusive que a Lei 11.101/05 não limita o prazo de duração do plano de recuperação aprovado. Logo, as condições previstas no plano podem perdurar vários anos, a mais, do que apenas os 7 anos (84 meses), previstos no artigo 10-A da Lei 10.522/2002, com redação dada pela Lei 13.043/2014;

b) para aderir, o contribuinte é obrigado a desistir de discutir, expressamente e de forma irrevogável, judicialmente ou extrajudicialmente, a legalidade da exigência. Os contribuintes, nesses casos de discussão já existentes, serão incentivados, racionalmente, a continuar a discutir a legalidade da cobrança, já que, como regra, em caso de discussão judicial ou administrativa, mediante apresentação de defesa, a exigibilidade do crédito já tende a ficar suspensa, ao longo de vários anos, considerando-se a notória morosidade das cobranças administrativas e judiciais de créditos fiscais no Brasil; ${ }^{30}$

c) considerando-se que o contribuinte em recuperação pode ter créditos parcelados ou não na época de seu pedido de recuperação, caso já possua algum parcelamento em aberto, que contenha condições mais atrativas, não irá desistir do já existente para aderir a este que prevê o parcelamento em apenas 84 vezes; ${ }^{31-32}$

${ }^{30}$ Lei 10.522/2002: "§ 2o No caso dos débitos que se encontrarem sob discussão administrativa ou judicial, submetidos ou não à causa legal de suspensão de exigibilidade, o sujeito passivo deverá comprovar que desistiu expressamente e de forma irrevogável da impugnação ou do recurso interposto, ou da ação judicial, e, cumulativamente, renunciou a quaisquer alegações de direito sobre as quais se fundem a ação judicial e o recurso administrativo. (Incluído pela Lei no 13.043, de 2014)." (BRASIL, 2002, online).

${ }^{31}$ Lei 10.522/2002: "§ 1o O disposto neste artigo aplica-se à totalidade dos débitos do empresário ou da sociedade empresária constituídos ou não, inscritos ou não em Dívida Ativa da União, mesmo que discutidos judicialmente em ação proposta pelo sujeito passivo ou em fase de execução fiscal já ajuizada, ressalvados exclusivamente os débitos incluídos em parcelamentos regidos por outras leis." (BRASIL, 2002, online).

${ }^{32}$ Vários já foram os parcelamentos (que podem estar ainda sendo quitados) que possibilitavam o pagamento em maior número de parcelas, sendo de 120 meses (10 anos); 130 (cerca de 11 anos); ou 180 meses (15 anos). O prazo de apenas 84 meses ( 5 anos) não maximiza interesses, riquezas e bemestar ao contribuinte, não incentivando à sua escolha racional. Ao longo dos anos, instituíram-se vários programas de parcelamento ou refinanciamento de débitos tributários. Tais programas, genericamente, se denominam "REFIS", e sua sigla se origina do primeiro parcelamento amplo e geral, realizado em 2000. São eles: REFIS 1 - O REFIS - Programa de Recuperação Fiscal - Lei 9.964/2000 destinava-se a promover a regularização dos créditos da União, decorrentes de débitos de pessoas jurídicas, relativos a tributos e contribuições administrados pela Secretaria da Receita Federal e pelo Instituto Nacional do Seguro Social, com vencimento até 29 de fevereiro de 2000. REFIS 2 (oficialmente: "PAES") - A Lei 10.684/2003, instituiu parcelamento especial de débitos em até 180 meses para todos os débitos para com a Fazenda Nacional (SRF e PGFN), constituídos ou não, inscritos ou não em Dívida Ativa da União, vencidos até 28 de fevereiro de 2003. REFIS 3 (Oficialmente: "PAEX") - A Medida Provisória 
d) se a recuperação judicial não for concedida, mediante aprovação do plano, ou se a falência for decretada, haverá a rescisão do parcelamento previsto no artigo 10-A da Lei 10.522/2002, incluído pela Lei 13.043/2014. Ao agir racionalmente, o contribuinte em recuperação, caso já possua algum parcelamento em aberto, que não contenha esse risco, não irá desistir do já existente para aderir ao previsto no artigo 10-A da Lei 10.522/2002, incluído pela Lei $13.043 / 2014 ;^{33}$

e) caso haja bem dado pelo recuperando em garantia de adesão a parcelamento já existente, ou dado em garantia em processo judicial, tal parcelamento previsto no artigo 10-A da Lei 10.522/2002, incluído pela Lei 13.043/2014, não implica liberação dos bens e direitos do devedor ou de seus responsáveis que tenham sido constituídos em garantia dos respectivos créditos; ${ }^{34}$

f) caso os devedores empresários não sejam Micro Empresas ou Empresas de Pequeno Porte e estejam em recuperação, para aderir a tal parcelamento previsto no artigo 10-A na Lei 10.522/2002, incluído pela Lei 13.043/2014, terão que dar bens em garantia real ou fidejussória, inclusive fiança bancária, idônea e suficiente para o pagamento do débito, que talvez

303/2006 instituiu parcelamento especial de débitos em até 130 (cento e trinta) prestações mensais e sucessivas para os débitos de pessoas jurídicas junto à Secretaria da Receita Federal - SRF, à Procuradoria-Geral da Fazenda Nacional - PGFN e ao Instituto Nacional do Seguro Social - INSS, com vencimento até 28 de fevereiro de 2003. REFIS 4 (também apelidado como "REFIS da Crise" e, posteriormente, em 2014, por "REFIS da Copa") - A Lei 11.941/2009 (conversão da MP 449/2008) permitia o parcelamento da dívidas tributárias federais vencidas até 30 de novembro de 2008 . O prazo de adesão ao programa de parcelamento do "REFIS da Crise" foi reaberto até 31.12.2013 pelo artigo 17 da Lei 12.865/2013. Posteriormente, criou-se mais 3 prazos de adesão, em 2014, sendo o último para 01.12.2014, este pela Lei 13.043/2014. Por meio da Lei $12.973 / 2014$, artigo 93, houve nova reabertura desse prazo, que finalizaria em 31.07.2014. Pela Lei $12.996 / 2014$, artigo $2^{\circ}$, o prazo de adesão foi ampliado para 25.08.2014 (data fixada pela MP 651/2014), compreendendo os débitos vencidos até 31.12.2013. REFIS das Autarquias e Fundações - o artigo 65 da Lei 12.249/2010 estipulou parcelamento dos débitos administrados pelas autarquias e fundações públicas federais e os débitos de qualquer natureza, tributários ou não tributários, com a Procuradoria-Geral Federal. O prazo de adesão a esse programa de parcelamento foi reaberto até 31.12.2013 pelo artigo 17 da Lei 12.865/2013. REFIS dos Bancos - instituído pelo artigo 39 da Lei 12.865/2013, trata do parcelamento de débitos do PIS e COFINS em até 60 parcelas, com descontos de multa e juros. REFIS dos Lucros no Exterior - instituído pelo artigo 40 da Lei 12.865/2013, trata do parcelamento de débitos do IRPJ e CSLL de lucros oriundos no exterior, em até 120 parcelas, com descontos de multa e juros. (grifo nosso).

${ }^{33}$ Lei 10.522/2002: "§ 4o Além das hipóteses previstas no art. 14-B, é causa de rescisão do parcelamento a não concessão da recuperação judicial de que trata o art. 58 da Lei no 11.101, de 9 de fevereiro de 2005, bem como a decretação da falência da pessoa jurídica." (BRASIL, 2002, online).

${ }^{34}$ Lei 10.522/2002: "§ 6o A concessão do parcelamento não implica a liberação dos bens e direitos do devedor ou de seus responsáveis que tenham sido constituídos em garantia dos respectivos créditos. (Incluído pela Lei no 13.043, de 2014).” (BRASIL, 2002, online). 
nem possuam. Tal ato, além de ser inconstitucional, poderá inclusive ter impedimento por parte do Comitê de Credores da Recuperação; 35-36-37-38

g) ao aderir ao parcelamento, o devedor em recuperação também se submeterá à grande ônus, já que o valor da parcela e cada prestação mensal, por ocasião do pagamento, serão acrescidos de juros equivalentes à taxa referencial do Sistema Especial de Liquidação e de Custódia - SELIC para títulos federais, acumulados mensalmente e calculados a partir do mês subsequente ao da consolidação, até o mês anterior ao do pagamento, acrescidos de $1 \%$ (um por cento); ${ }^{39}$

${ }^{35}$ As letras "b" e "f", inclusive, tratam de exigências criadas pela lei que, a nosso ver, são inconstitucionais. Isso, pois impor ao contribuinte a renúncia ou ônus para o exercício de um direito que a Constituição da República / 1998 lhe assegura e garante, é legislar de forma abusiva. Ademais, o STF, interpretando o caput do artigo 150 da Constituição da República / 1998, já decidira: "O Estado não pode legislar abusivamente, eis que todas as normas emanadas do Poder Público, tratando-se, ou não, de matéria tributária, devem ajustar-se à cláusula que consagra, em sua dimensão material, o princípio do substantive due process of law ( $5^{\circ}$, LIV). O postulado da proporcionalidade qualifica-se como parâmetro de aferição da própria constitucionalidade material dos atos estatais. Hipótese em que a legislação tributária se reveste do necessário coeficiente de razoabilidade." (STF RE 200.844-AgR, Rel. Min. Celso de Mello, julgamento em 25-06-2002, Segunda Turma, DJ de 16-08-2002)". Há, ademais, a interpretação do STF sobre o inciso LV da Constituição contida na Súmula Vinculante n. 28: "É inconstitucional a exigência de depósito prévio como requisito de admissibilidade de ação judicial na qual se pretenda discutir a exigibilidade de crédito tributário." E o STF editou a Súmula Vinculante n. 21, considerando inconstitucional a exigência de depósito ou arrolamento prévio de dinheiro ou bens para admissibilidade de recurso administrativo. O Poder Público não pode criar qualquer tipo de restrição ao exercício de direitos constitucionais.(BRASIL, 2002).

${ }^{36}$ Lei 11.101/05: "Art. 27. O Comitê de Credores terá as seguintes atribuições, além de outras previstas nesta Lei: [...] c) submeter à autorização do juiz, quando ocorrer o afastamento do devedor nas hipóteses previstas nesta Lei, a alienação de bens do ativo permanente, a constituição de ônus reais e outras garantias, bem como atos de endividamento necessários à continuação da atividade empresarial durante o período que antecede a aprovação do plano de recuperação judicial.” (BRASIL, 2005, online).

37 “\$ 1o Observados os limites e as condições estabelecidos em portaria do Ministro de Estado da Fazenda, em se tratando de débitos inscritos em Dívida Ativa, a concessão do parcelamento fica condicionada à apresentação, pelo devedor, de garantia real ou fidejussória, inclusive fiança bancária, idônea e suficiente para o pagamento do débito, exceto quando se tratar de microempresas e empresas de pequeno porte optantes pela inscrição no Sistema Integrado de Pagamento de Impostos e Contribuições das Microempresas e das Empresas de Pequeno Porte - Simples, de que trata a Lei no 9.317, de 5 de dezembro de 1996.\$ 2o Enquanto não deferido o pedido, o devedor fica obrigado a recolher, a cada mês, como antecipação, valor correspondente a uma parcela. § 3o $O$ não cumprimento do disposto neste artigo implicará o indeferimento do pedido." (BRASIL, 2002, online).

${ }^{38} \mathrm{~A}$ Portaria Conjunta $\mathrm{n}^{\circ} 1$ também reafirma que a adesão ao programa não libera bens ou direitos da empresa, que tenham sido constituídos como garantia.

${ }^{39}$ Lei 10.522/2002: “Art. 13. O valor de cada prestação mensal, por ocasião do pagamento, será acrescido de juros equivalentes à taxa referencial do Sistema Especial de Liquidação e de Custódia - SELIC para títulos federais, acumulada mensalmente, calculados a partir do mês subsequente ao da consolidação até o mês anterior ao do pagamento, e de $1 \%$ (um por cento) relativamente ao mês em que o pagamento estiver sendo efetuado. (Redação dada pela Lei no 11.941, de 2009)." (BRASIL, 2002, online). 
h) a Lei 13.043/14 mostra-se incompleta ao tratar somente de tributos federais, e isso não atende exigência contida no art. 57 da LRF. O problema do parcelamento continua no que diz respeito às dívidas fiscais estaduais e municipais, de cada ente.

Veja-se ademais que o requerimento do parcelamento poderá ser feito com o pedido de recuperação judicial. Mas, se a recuperação for negada, o parcelamento será rescindido.

No entanto, o que mais chama a atenção é o aspecto negativo, pois é preciso incluir a totalidade dos débitos da empresa no parcelamento, inclusive os relativos a contribuições previdenciárias. E, se os débitos incluídos estiverem sendo discutidos na esfera administrativa ou judicial, a desistência dos processos deverá ser comprovada expressamente e de forma irrevogável. Além disso, o devedor poderá ter apenas um parcelamento referente à recuperação judicial. Para Salomão e Santos (2015, online):

Apesar de a Lei n. 13.043, de 13.11.14, ter instituído o parcelamento especial para as sociedades em recuperação judicial, em linha de princípio ela não representa um direito, propriamente dito, para o contribuinte, tendo em vista que a possibilidade de parcelamento está subordinada a condições extremamente onerosas para a sociedade em recuperação, em desacordo com o principio da preservação da empresa. Por isso mesmo, prestes a completar dez anos de vigência, o grande desafio do direito falimentar moderno e da lei de recuperação brasileira, é manter o equilíbrio entre o interesse social com o soerguimento da empresa, a satisfação dos credores e o respeito aos direitos do devedor.

Nas palavras de Waisberg (2015):

No caso em questão, ao impedir por anos a promulgação da lei especial e, finalmente, ao fazê-lo por meio da Lei n. ${ }^{\circ}$ 13.043/14, estabelece algo insuficiente. Foram "apenas" 84 meses sem nenhum desconto ou qualquer outro método para viabilizar a efetiva recuperação da atividade econômica, e em seguida a Lei n. ${ }^{\circ}$ 13.043/14, por meio da qual o fisco simplesmente deixa de contribuir com sua parte, mantendo a ausência de qualquer desconto ou benefício que pudesse contribuir para a recuperação da empresa; além de tentar imputar todo o ônus do processo aos demais credores. Ademais, se a razão econômica de um plano é uma equilibrada correlação entre capacidade de geração de caixa e fluxo de pagamentos, o fisco, ao agir de maneira costumeira, acaba por simplesmente impedir que qualquer solução fique de pé, onerando a empresa (WAISBERG, 2015, p. 352).

Apenas 9 anos após a promulgação da LRE é que o fisco federal resolveu Editar lei com o previsto parcelamento especial para as empresas em recuperação judicial. Além de tardia, tal iniciativa foi acanhada e insuficiente (WAISBERG, 2015, p. 352).

O espírito da lei é a recuperação da empresa e manutenção da atividade econômica, ambos princípios corolários de outros princípios constitucionais e, 
com certeza, matéria de interesse público. Mas o interesse da Receita Federal parece ser somente o seu, completamente decolado do interesse social. Isto fica provado com a sua insanável sede arrecadatória, muitas vezes completamente míope no longo prazo (WAISBERG, 2015, p. 352).

Esta visão deturpada certamente levará a uma redução e não aumento de sua sagrada arrecadação, pois no médio prazo o que está o Estado fazendo é matar a fonte geradora de tributos futuros para tentar receber dívidas passadas, o que provavelmente também não ocorrerá no cenário falimentar. Duas seriam as soluções possíveis (i) realizar as alterações legislativas e constitucionais necessárias para que o fisco participasse da recuperação judicial em condições apropriadas e negociasse o respectivo plano de recuperação com base em critérios econômicos; ou (ii) alterações da Lei n. ${ }^{\circ}$ 13.043/14 para que, entre outros fatores, o parcelamento dos tributos, entre 120 e 180 meses, redução parcial de multas e juros (WAISBERG, 2015, p. 353).

Acredita-se, neste artigo, de forma respeitosa, que a solução não é de fácil deslinde.

\section{INAPLICABILIDADE CONSTITUCIONAL, LEGAL, OPERACIONAL E PRÁTICA: INEFICIÊNCIA E ALTO CUSTO DE TRANSAÇÃO}

Em que pese aos notáveis posicionamentos em contrário, por hora, de forma respeitosa, entende-se, neste artigo, que em nosso ordenamento é impossível, legalmente 40-41-42, operacionalmente e constitucionalmente ${ }^{43-44}$, a inclusão no plano de recuperação

${ }^{40}$ Lei $n^{\circ}$ 5.172, de 25 de outubro de 1966. - CTN: "Art. 141. O crédito tributário regularmente constituído somente se modifica ou extingue, ou tem sua exigibilidade suspensa ou excluída, nos casos previstos nesta Lei, fora dos quais não podem ser dispensadas, sob pena de responsabilidade funcional na forma da lei, a sua efetivação ou as respectivas garantias. Art. 187. A cobrança judicial do crédito tributário não é sujeita a concurso de credores ou habilitação em falência, recuperação judicial, concordata, inventário ou arrolamento.” (BRASIL, 1966, online, grifo nosso).

${ }^{41}$ Lei no 6.830, de 22 de setembro de 1980: "Art. 29 - A cobrança judicial da Dívida Ativa da Fazenda Pública não é sujeita a concurso de credores ou habilitação em falência, concordata, liquidação, inventário ou arrolamento. Art. 38 - A discussão judicial da Dívida Ativa da Fazenda Pública só é admissível em execução, na forma desta Lei, salvo as hipóteses de mandado de segurança, ação de repetição do indébito ou ação anulatória do ato declarativo da dívida, esta precedida do depósito preparatório do valor do débito, monetariamente corrigido e acrescido dos juros e multa de mora e demais encargos. Parágrafo Único - A propositura, pelo contribuinte, da ação prevista neste artigo importa em renúncia ao poder de recorrer na esfera administrativa e desistência do recurso acaso interposto." (BRASIL, 1980, online, grifo nosso).

${ }^{42}$ Enseja, a depender da disposição do bem público, responsabilidade funcional do agente público.

${ }^{43}$ Haveria nítida ofensa ao princípio Indisponibilidade do Interesse Público. Tem-se aqui interesse público em seu sentido amplo, abrangendo todo o patrimônio público e todos os direitos e interesses do povo em geral. Deste princípio derivam todas as restrições especiais impostas à atividade administrativa. Elas existem pelo fato de a Administração Pública não ser dona da coisa pública, e sim mera gestora de bens e interesses públicos. Os bens e interesses públicos são indisponíveis à Administração Pública, bem como a seus agentes públicos, pertencendo à coletividade e ao povo. Em

64 R. Opin. Jur., Fortaleza, ano 19, n. 31, p.33-74, maio/ago. 2021 
dos créditos tributários.

Sabe-se da existência dos princípios da legalidade administrativa, indisponibilidade do bem público e interesse público, impessoalidade e respeitável doutrina, que defende a sua relativização e transação do crédito tributário no caso concreto. ${ }^{45}$ Em termos operacionais, práticos e realistas, não há como, atualmente, considerando-se o sistema tributário brasileiro, de forma eficiente e com baixo custo de transação, estabelecer, em cada Estado ou Município, bem como na Federação:

a) entre as várias espécies de tributos, Federais, Estaduais ou Municipais, qual ou quais poderiam ser perdoados ou transacionados, e a que tipo de contribuinte;

b) dentre as inúmeras hipóteses, inclusive as previstas no artigo 50 da Lei 11.101/05, quais seriam as condições de parcelamento ou pagamento para cada tributo;

c) como seria realizado em relação aos optantes do Simples Nacional, o qual se refere a vários tributos, de entes federativos diferentes, pagos na mesma guia de recolhimento;

d) qual o valor ou percentual de cada perdão seria concedido, para cada tributo e a que tipo de contribuinte e atividade;

e) qual seria o setor público, ou qual agente, ou grupo de agentes, de cada Estado, Município e Federação, responsável pela validação dos valores e condições, sob pena de responsabilidade funcional dos agentes;

f) qual setor público, ou qual agente, ou grupo de agentes, de cada Estado, Município e Federação, representaria o credor fiscal na assembleia geral de credores;

razão do Princípio da Indisponibilidade do Interesse Público, são vedados ao administrador quaisquer atos que impliquem renúncia a direitos do Poder Público ou que injustificadamente onerem a sociedade. Deste princípio decorrem diversos princípios expressos que norteiam a atividade da Administração, como os da legalidade, impessoalidade, moralidade e eficiência.

${ }^{44}$ Não obstante, deve ser levado em consideração o princípio da indisponibilidade do interesse público, que impede o Estado de abdicar de suas prerrogativas, devendo exercer toda a extensão de sua capacidade tributária de forma a aumentar a eficiência na arrecadação. Destarte, o administrador público não tem outra alternativa senão promover a inscrição dos débitos em dívida ativa e promover sua execução, nos termos da legislação específica, com o resguardo de todos os seus privilégios (LOPES, 2008, p. 126).

${ }^{45}$ Ver: (BATISTA JÚNIOR, 2007, p. 509-521; BUSA, 2008, p. 538; CARVALHO, 2007. p. 38-39, p. 119-123; GODOY, 2010; OLIVEIRA, 2015. p. 85, 111, 135, 143-207, 216). Há também a fundamentação com esteio no próprio Código Tributário Nacional: Art. 172. A lei pode autorizar a autoridade administrativa a conceder, por despacho fundamentado, remissão total ou parcial do crédito tributário, atendendo: I - à situação econômica do sujeito passivo; II - ao erro ou ignorância excusáveis do sujeito passivo, quanto a matéria de fato; III - à diminuta importância do crédito tributário; IV - a considerações de eqüidade, em relação com as características pessoais ou materiais do caso; $\mathrm{V}$ - a condições peculiares a determinada região do território da entidade tributante. 
g) qual seria o critério de apuração de quórum em assembleia geral de credores, destinado a qual setor público, ou agente, ou grupo de agentes, de cada Estado, Município e Federação.

Entende-se, neste artigo, que o atual regramento para tal parcelamento, economicamente, não é eficiente, já que o custo de transação é alto, não incentiva positivamente a sua adesão, não promove maximização do bem-estar, não promove maximização de riquezas, não promove a maximização de interesses do devedor, e não o fará fazer a escolha racional pela sua adesão. Há sim maior necessidade de jogo de cooperação entre o credor Fazendário e o devedor em recuperação, de modo a aumentar o grau de previsibilidade de êxito após a adesão a parcelamento tributário, para que fossem reduzidos os riscos de inadimplemento após adesão, em maior barganha com o credor Fiscal, que possa ter sucesso e eficiência.

A publicação da referida Lei 13.043/14 ensejou a reflexão acerca da possibilidade de continuar-se a dispensar a apresentação de certidão negativa de débito tributário ou de certidão positiva com efeitos de negativa para conceder-se recuperação judicial. Entende-se, neste artigo, que deve continuar a ser dispensada, sob pena de mácula ao princípio da preservação da empresa. No mesmo sentido Cavalli (2016):

O parcelamento ordinário de tributos federais é permanente e permite que se pague o passivo tributário em até 60 meses. A jurisprudência consolidada entendia que esse parcelamento ordinário era absolutamente insuficiente ao objetivo de preservar-se a empresa, razão pela qual autorizava a concessão da recuperação judicial com dispensa de apresentação de certidões negativas ou positivas com efeitos de negativas. O Fisco não se deu por rogado e em 2014 fez promulgar a Lei 13.043/14, em cujo art. 43 dispôs sobre o parcelamento do passivo tributário de empresas em recuperação judicial. Com esse movimento, esperava o Fisco que a jurisprudência passasse a exigir a apresentação de certidões negativas ou positivas com efeitos de negativa para fins de concessão de recuperação judicial. Ocorre que o parcelamento regulamentado pela Lei $13.043 / 14$ de especial nada tem. A empresa devedora precisa confessar todas as suas dívidas tributárias (mesmo as prescritas) e aderir a um parcelamento de até 84 meses. Como se vê, o prazo previsto na Lei 13.043/14 é muito próximo ao do parcelamento ordinário de 60 meses, que fez com que a jurisprudência passasse a dispensar a apresentação de CNDs e CPcEN para a concessão de recuperação judicial. $O$ fundamento da jurisprudência consolidada nos tribunais fundava-se em uma análise meio-fim, isto é, na inadequação do parcelamento ordinário para promover a preservação da empresa. A necessidade de adequação entre meios e fins, enquanto exigência constitucional a permear todo o ordenamento jurídico brasileiro, continua a orientar a análise da relação entre a regulamentação do parcelamento tributário de empresa em recuperação e o fim de preservar-se empresas. A questão que se coloca, portanto, não é se existe ou não, formalmente, uma Lei a regulamentar o parcelamento do passivo tributário de empresa em recuperação, mas se o parcelamento existente, qualquer que seja ele, constitui meio adequado a promover-se o fim de preservar empresas. À toda evidência, parcelamento de até 84 meses de 
especial nada tem e, mais do que isso, é inadequado a promover o fim de preservar empresas. Por essa razão, nos casos concretos de recuperação judicial deve-se continuar a dispensar-se a exigência de apresentação de certidões para fins de concessão da recuperação judicial, ante a manifesta inadequação do parcelamento contido na Lei $13.043 / 14$ a promover o princípio da preservação da empresa (CAVALLI, 2016, grifo nosso).

\section{Também:}

[...] A Lei n. 13.043 de 13 de novembro de 2014. O art. 43 da Lei n. 13.043 de 13 de novembro de 2014 conferiu nova redação ao artigo 10-A da Lei n. 10522, de 19 de julho de 2002, instituindo um parcelamento específico para o pagamento das dívidas tributárias de sociedades em recuperação judicial. Todavia, parece, a partir de um exame mais acurado da questão, que a simples edição de Lei especial, da forma como foi disposta, não resolve a questão. É bem de ver que, em cumprimento ao artigo 44 da Lei n. 13.043/14, sobreveio a Portaria Conjunta 01, do Procurador Geral da Fazenda Nacional e do Secretário da Receita Federal, publicada no D.O.U. de 18 de fevereiro, pretendendo dispor sobre o parcelamento de débitos para com a Fazenda Nacional, e em um capítulo específico (alterando a anterior portaria conjunta sobre o mesmo tema), disciplinou o parcelamento para as pessoas jurídicas em recuperação judicial. De início, parece que a portaria conjunta baralha alguns conceitos e funções, especialmente em relação ao administrador judicial, exigindo sua assinatura no requerimento de parcelamento. Contudo, na recuperação judicial, o papel do administrador é bem outro, justamente o de, primordialmente, fiscalizar as atividades do devedor e o cumprimento do plano de recuperação. Note-se, ademais, que o problema do parcelamento continua no que diz respeito às dívidas fiscais estaduais e municipais. Além disso, outros dois pontos merecem análise mais acurada em relação ao parcelamento específico para o pagamento das dívidas tributárias de sociedades em recuperação judicial. São os previstos, respectivamente, nos parágrafos primeiro e segundo do referido artigo 44, da Lei de regência. No primeiro, o legislador exige que o contribuinte inclua no parcelamento a totalidade de seus débitos tributários, inscritos ou não em dívida ativa, mesmo que discutidos judicialmente. De outro lado, o parágrafo segundo condiciona a concessão do parcelamento à desistência expressa, e de forma irrevogável, de qualquer impugnação, ação ou recurso e cumulativamente, a quaisquer alegações de direito sobre as quais se fundem as lides administrativas e judiciais. Essas duas exigências, criadas pela Lei e repetidas na portaria regulamentadora, são de constitucionalidade duvidosa. Em ambos os casos, impor ao contribuinte a renúncia ou ônus para o exercício de um direito que a Constituição da República lhe assegura, pode significar legislar de forma abusiva. [...]. Por tais fundamentos, percebe-se que o parcelamento instituído pela Lei n. 13.043 de 13 de novembro de 2014 para as sociedades em recuperação judicial não representa um direito propriamente dito do contribuinte, na medida em que o seu exercício está condicionado a outros atos de duvidosa constitucionalidade (SALOMÃO; SANTOS, 2015, online) .

Diante dessa legislação ineficiente, exigir a quitação dos créditos tributários como requisito para concessão da recuperação é forma indireta de se cobrar o tributo em aberto, eivada de inconstitucionalidade. Nesse sentido, Lopes (2008, p. 218): 
Nos ensinamentos de Hugo de Brito, a exigência de certidão negativa de débito tributário constitui forma oblíqua de burlar as garantias instituídas no artigo 5, incisos LIV e LV da Constituição da República de 1988, ou seja, burla ao devido processo legal, bem como do direito da ampla defesa e contraditório com os meios e recursos a ele inerentes.

Para Machado (2005, p. 219):

A exigência de quitação de tributos será inconstitucional, ainda que estabelecida em Lei complementar federal, na medida em que implicar cerceamento da liberdade de exercício da atividade econômica, ou propiciar ao fisco a cobrança do tributo sem o devido processo legal, vale dizer, sem a apuração em regular processo administrativo, e sem o uso da via própria, que é a execução fiscal [...] Entre as duas possibilidades existentes para solucionar o problema, declarando inconstitucional a norma ou dando à mesma interpretação em conformidade com a Constituição e os objetivos da recuperação judicial, a segunda é mais vantajosa à Administração Tributária, pois permitirá que o crédito tributário seja parcelado e também que o cumprimento das obrigações seja fiscalizado pelo Juízo da Falência.

No mesmo sentido, por fim, entende-se, neste artigo, que por ser, neste ponto, ineficiente a Lei 13.043/14, deve ser mantida a dispensa de certidão negativa de débito tributário ou de certidão positiva com efeitos de negativa para a concessão da recuperação judicial. ${ }^{46}$

\section{CONCLUSÃO}

As linhas escritas neste artigo pretenderam ser respeitosas, baseadas na doutrina

${ }^{46}$ Ver: Agravo de Instrumento no 0050788-91.2015.8.19.0000, Relator Desembargador Luciano Saboia Rinaldi de Carvalho, 7a Câmara Cível, TJRJ. Decidiu-se que a Lei 13.043/14 não justifica a exigibilidade de apresentação de CND para os casos ajuizados antes de sua entrada em vigor, ocorrida em 13.11.2014, em razão do princípio tempus regit actum, aliado à necessidade de promover-se a segurança jurídica nos casos de recuperação judicial. Ademais, mesmo para casos de recuperação judicial posteriores à entrada em vigor da Lei 13.043/14, recordou o Des. Rinaldi que a Lei 13.043/14 é incompleta, pois trata apenas de tributos federais. Por essa razão, "o parcelamento especial concebido pela Lei $\mathrm{n}^{\circ}$ 13.043/2014, por incompleto, não atende a exigência contida no art. 57 da LRF, devendo, por conseguinte, ser mantida a jurisprudência prevalecente na Corte Superior a respeito do tema, no sentido de permitir a dispensa das certidões negativas para fins de homologação do plano de recuperação." Consignou-se que "urge reconhecer que, em muitos casos, os artigos 47 e 57 da LRF são inconciliáveis, levando à inviabilização dos processos de recuperação judicial e, por consequência, impedindo o soerguimento da empresa em dificuldades financeiras. Embora a homologação do plano de recuperação esteja condicionada à apresentação das certidões negativas de débitos fiscais (art. 57, LRF, e art. 191-A, CTN), deve preponderar o princípio da preservação da empresa, insculpido no art. 47 da Lei Recuperacional, cujo propósito maior é proteger a fonte produtora, o emprego, a função social da empresa e o estímulo à atividade econômica." (RIO DE JANEIRO, 2015, online). 
especializada no cerne do tema, nacional e estrangeira, sem pretender esgotar o tema. De fato, é dado tratamento de forma especial em relação às execuções fiscais, as quais, estas, além de não se submeterem ao concurso na recuperação judicial, não sofrem os efeitos da concessão da recuperação judicial. Assim, cumprirá ao recuperando quitar o seu crédito tributário ou parcelá-lo administrativamente, entre a data do pedido de recuperação e a juntada aos autos do plano de recuperação, nos termos, frise-se, literais, da Lei.

Não se olvida acerca da importância do crédito tributário a ser pago, inclusive, sobretudo, tendo-se como referência o interesse do próprio Estado. Acredita-se, inclusive, que, em regra, nos momentos de crise econômica e financeira, o Estado seja o maior credor no Brasil.

Entende-se, neste artigo, que o poder e privilégio concedido ao Fisco, frise-se, tal como está, nos termos literais da lei, nos processos de recuperação judicial, é ineficiente. As condições de parcelamento que vigoraram por muitos anos também não eram eficientes. As condições atuais para pagamentos dos créditos tributários foram previstas, apenas recentemente, após cerca de 11 anos de vigência da Lei 11.101/05, com a inclusão do artigo 10-A na Lei 10.522/2002, inclusão esta trazida pela Lei 13.043/2014. Esse dispositivo possibilitou aos empresários em processamento de recuperação judicial o parcelamento dos débitos com a Fazenda Nacional em até 84 parcelas mensais e consecutivas. Foram expostos os motivos pelos quais se entende neste trabalho que a legislação atual não cria incentivos positivos ao contribuinte, com créditos tributários em aberto, que esteja em recuperação, a aderir tal parcelamento.

Tratou-se também dos motivos pelos quais, apesar dos notáveis posicionamentos doutrinários em contrário, por hora, de forma respeitosa, entende-se, neste artigo, que, em nosso ordenamento, seja impossível, legalmente, operacionalmente e constitucionalmente, inserir no plano de recuperação os créditos tributários, tendo em vista, inclusive, o alto custo de transação.

No mesmo sentido, almejou-se demonstrar que o atual regramento para parcelamento tributário, economicamente, não é eficiente, já que o custo de transação também é alto e não incentiva positivamente a sua adesão, não promove maximização do bem-estar, não promove maximização de riquezas, não promove a maximização de interesses do devedor, e não o fará fazer a escolha racional pela sua adesão.

Procurou-se mostrar que há sim maior necessidade de jogo de cooperação entre o credor Fazendário e o devedor em recuperação, de modo a aumentar o grau de previsibilidade de êxito após a adesão a parcelamento tributário, de modo a reduzir os riscos de inadimplemento após adesão, tendo-se maior barganha com o credor Fiscal, permitindo-se obter sucesso e eficiência.

Ao final, abordou-se que, por ser ineficiente a Lei 13.043/14, merece ser mantida 
a dispensa de certidão negativa de débito tributário ou de certidão positiva com efeitos de negativa para a concessão da recuperação judicial.

\section{REFERENNCIAS}

ABRÃO, Carlos Henrique. Comentários aos arts. 70 ao 104. In: ABRÃO, Carlos Henrique; TOLEDO, Paulo F. C. Salles de (coord.). Comentário à lei de recuperação de empresas e falência. 3. ed. São Paulo: Saraiva, 2009.

BARBOSA, Luiz Roberto Peroba. Da sucessão tributária e previdenciária e do parcelamento dos débitos tributários. In: PAIVA, Luiz Fernando Valente (coord.) Direito Falimentar a nova lei de falências e recuperação de empresas. São Paulo: QuartierLatin, 2005. p. 725-735.

BARROS NETO, Geraldo Fonseca de. Aspectos processuais da recuperação judicial. 2012. 71 f. Dissertação (Mestrado em Direito) - PUC, São Paulo, 2012.

BATISTA JÚNIOR, Onofre Alves Batista. Transações Administrativas. Belo Horizonte: Quartier Latim do Brasil, 2007.

BERTOLDI, Marcelo Marco; RIBEIRO, Márcia Carla Pereira. Curso avançado de direito comercial: títulos de crédito, falência e concordata, contratos mercantis. 3. ed. São Paulo: Revista dos Tribunais, 2006.

BEZERRA FILHO. A nova lei de recuperação e falências comentada. 3. ed. São Paulo: Revista dos Tribunais, 2005.

BORGES, João Eunápio. Curso de direito territorial terrestre. Rio de Janeiro: Forense, 1968.

BRANQUINHO, Dalmo; CREMONINI, Daniel. Parcelamentos de créditos tributários da empresa em recuperação judicial. 2016. Disponível em: http://www.diariodafranca.com.br/conteudo/noticia.php? noticia=25798\& categoria=1. Acesso em: 27 maio 2016.

BRASIL. Lei $\mathrm{n}^{\circ}$ 10.522, de 19 de julho de 2002. Dispõe sobre o Cadastro Informativo dos créditos não quitados de órgãos e entidades federais e dá outras providências. Diário Oficial da União, Brasília, 22 jul. 2002. Disponível em: http://www.planalto. gov.br/ccivil_03/leis/2002/L10522.htm. Acesso em: 18 maio 2017.

BRASIL. Lei no 11.101, de 9 de fevereiro de 2005. Regula a recuperação judicial, a extrajudicial e a falência do empresário e da sociedade empresária. Diário Oficial da União, Brasília, 9 fev. 2005. Disponível em: http://www.planalto.gov.br/ccivil_03/_ato2004-2006/2005/lei/111101.htm. Acesso em: 2 fev. 2015. 
BRASIL. Lei no 5.172, de 25 de outubro de 1966. Dispõe sobre o Sistema Tributário Nacional e institui normas gerais de direito tributário aplicáveis à União, Estados e Municípios. Diário Oficial da União, Brasília, 27 out. 1966. Disponível em: http://www.planalto.gov .br/ccivil_03/Leis/L5172.htm. Acesso em: 19 set. 2016.

BRASIL. Lei $n^{\circ}$ 6.830, de 22 de setembro de 1980. Dispõe sobre a cobrança judicial da Dívida Ativa da Fazenda Pública, e dá outras providências. Diário Oficial da União, Brasília, 24 set. $1980 . \quad$ Disponível em: http://www.planalto.gov.br/ccivil_03/leis/L6830.htm. Acesso em: 19 maio 2017.

BUSA, Vincenzo. Gliinstitutideflaviti del contenziosonell' esperienza italiana: a experiência italiana sobre transação e conciliação em matéria tributária e demais modalidades alternativas de solução de controvérsias fiscais. In: TÔRRES, Heleno Taveira (coord.). Direito tributário internacional aplicado. São Paulo: QuartierLatin, 2008. p. 538.

CARVALHO, Rubens Miranda de Carvalho. Transação tributária, arbitragem e outras formas convencionadas de solução de lides tributárias. São Paulo: Editora Juares de Oliveira, 2007.

CAVAlli, Cássio. A compensação jurídica do dever de razoabilidade. Revista de Direito Constitucional e Internacional, v. 13, n. 50, p. 220-243, 2005.

CAVALLI, Cassio. A dispensa de CND para concessão da recuperação judicial após a lei 13.043/14. [S.l.]: Do Autor, 2016. Disponível em: http://www.cassiocavalli.com.br/?p=494. Acesso em: 25 out. 16.

CAVALLI, Cássio. Reflexões sobre a recuperação judicial: uma análise da aferição da viabilidade econômica como pressuposto para o deferimento do processamento da recuperação judicial. In: MENDES, Bernardo Bicalho de Alvarenga (org.). Aspectos polêmicos e atuais da Lei de recuperação de empresas. Belo Horizonte: Editora D' Plácido, 2016. p. 1303-1331.

COMPARATO, Fábio Konder. Aspectos jurídicos da macro-empresa. São Paulo: RT, 1970.

GUIMARÃES, Maria Celeste Morais. Entraves à eficácia da Lei de recuperação de empresas em crise. Como superá-los? Revista da Faculdade de Direito da UFMG, Belo Horizonte, n. 50, p. 265-280, jan./ jul. 2007a.

GUIMARÃES, Maria Celeste Morais. Recuperação judicial de empresas. Belo Horizonte: Del Rey, 2007b. p. 105-109.

JOHNSON, Gordon W. Nova lei brasileira de falência e recuperação de empresas: uma comparação com as normas internacionais. In: OLIVEIRA, Fátima Bayma de Oliveira (org.). Recuperação de empresas: uma múltipla visão da nova lei. São Paulo: Pearson 
Prentice Hall, 2006.

LISBOA, Marcos de Barros et al. A racionalidade econômica da nova lei de falências e de recuperação de empresas. In: PAIVA, Luiz Fernando Valente de; LISBOA, Marcos de Barros (org.). Direito falimentar e a nova lei de falências e recuperação de empresas. São Paulo: QuartierLatin, 2005. v. 1. p. 325-351.

LOPES, Braulio Lisboa. Aspectos tributários da falência de recuperação de empresas. São Paulo: [s.n.], 2008.

LÓPEZ-ÍBOR, Rocio; ARTÉS-CASELLES, Joaquín. Bankruptcy proceedings and government: should bankruptcy law grant privileges to the theasury? paper 9, 2003. Disponível em: www.bepress.com/gwp/default/vol2003/iss1/art9. Acesso em: 1 set. 2016.

MACHADO, Celso Cordeiro. Tratado de direito tributário brasileiro: garantias, preferências e privilégios do crédito tributário. Rio de Janeiro: Forense, 1984. v. 6.

MACHADO, Hugo de Brito. Dívida tributária e recuperação judicial de empresa. Revista Dialética de Direito Tributário, n. 120, p. 70, set. 2005.

MANDEL, JulioKahan. Das disposições comuns. In: PAIVA, Luiz Fernando Valente (org.) Direito falimentar e a nova lei de falências e recuperação judicial. São Paulo: QuartierLatin, 2005.

MIRETTI, Luiz Antônio Caldeira. Comentários à nova lei de falências e recuperação de empresas. Coordenação de Rubens Aprobbato Machado. São Paulo: Ed. QuartierLatin, 2005.

MUNHOZ, Eduardo Secchi. Comentários aos artigos 55 a 69. In: SOUZA JUNIOR, Francisco Satiro de; PITOMBO, Antônio Sérgio A. de Moraes (org.). Comentários à Lei de recuperação de empresas e falência. São Paulo: Revista dos Tribunais, 2006.

OLIVEIRA, Phelippe Toledo Pires de. A transação em matéria tributária. São Paulo: Quartier Latim, 2015.

PERIN JUNIOR, Ecio. O Administrador Judicial e o Comitê de Credores. In: PAIVA, Luiz Fernando Valente de (org.). Direito falimentar e a nova lei de falências e recuperação de empresas. São Paulo: Quartier Latin, 2005.

PIMENTA, Eduardo Goulart. O estabelecimento. In: RODRIGUES, Frederico Viana (org.). Direito de empresa no novo código civil. Rio de Janeiro: Forense, 2004.

PIMENTA, Eduardo Goulart. Recuperação de empresas: um estudo sistematizado. São Paulo: IOB Thomson, 2006.

PROENÇA, José Marcelo Martins. Disposições Preliminares. Aplicação da legislação,

72 • R. Opin. Jur., Fortaleza, ano 19, n. 31, p.33-74, maio/ago. 2021 
competência e intervenção do Ministério Público. In: MACHADO, Rubens Approbato. (org.). Comentários à nova lei de falências e recuperação de empresas: doutrina e prática. São Paulo: Quartier Latin, 2005. p. 47-72.

RIO DE JANEIRO. Tribunal de Justiça. Agravo de Instrumento: AI 00507889120158190000 Capital 1 Vara Empresarial. Luciano Sabóia Rinaldi de Carvalho. Sétima Câmara Cível. Tribunal de Justiça, Rio de Janeiro, 21 jan. 2016. Disponível em: https://tj-rj.jusbrasil.com.br/jurisprudencia/359716147/agravo-deinstrumento-ai-507889120158190000-rio-de-janeiro-capital-1-vara-empresarial. Acesso em: 19 maio 2017.

SALOMÃO, Luis Felipe; SANTOS, Paulo Penalva. A lei de recuperação judicial e a questão tributária. 2015. Disponível em: http://jota.uol.com.br/lei-de-recuperacaojudicial-e-questao-tributaria. Acesso em: 22 out. 2016.

SANTOS JÚNIOR, Clélio Gomes dos. Dos efeitos da falência sobre os créditos tributários. 2010. 110f. Dissertação (Mestrado em Direito Empresarial) - Faculdades Milton Campos, Belo Horizonte, 2010.

WAISBERG, Ivo. 10 anos da recuperação judicial: sugestões para reforma legislativa. [S.l.: s.n.], 2015.

ZANETTI, Robson. A prevenção de dificuldades e recuperação de empresas. Curitiba: Juruá, 2000.

\section{NOTA}

Após discussões em seminários e apresentações de trabalhos, em conjunto, ambos os autores, entenderam que via ferramentas metodológicas da Análise Econômica do Direito, tais como incentivos, maximização de interesses, maximização de bem estar i riquezas, escolha racional, custos de transação e eficiência, seria possível identificar, de forma construtiva, sem almejar esgotar o tema, que a atual redação da Lei 11.101/05, no que toca sobre o crédito tributário, contribui para a sua ineficiência. Em conjunto, ambos os autores entenderam que a metodologia a ser utilizada seria a de método dedutivo, bibliográfica, nacional e estrangeira, toda ela especializada no cerne do tema. Inicialmente, o Autor Henrique Avelino cogitava de que o problema específico a ser levantando seria saber se seria possível incluir o crédito tributário no plano de recuperação judicial. No mesmo sentido, o Autor Eduardo Goulart Pimenta sugeriu que para obter-se uma resposta que fosse técnica, prática e acadêmica, inicialmente, seria explicado sobre o tratamento especial dado ao crédito tributário na Lei 11.101/05. Após, em conjunto, ambos os autores entenderam sugeriram fosse mostrado que o 
poder e privilégio concedido ao Fisco, frise-se, tal como está, nos termos literais da lei, nos processos de recuperação judicial, seria ineficiente e, que, as condições de parcelamento que vigoraram por muitos anos também não seriam eficientes. E, de modo a se dar coesão e coerência ao tema, ambos os autores entenderam por expor os motivos que denotariam que a lei 11.101/05 não cria incentivos positivos ao contribuinte a aderir tal parcelamento. Ao final, como hipótese de resposta, ambos os autores abordaram os motivos que fazem com que, em nosso ordenamento seja impossivel, legalmente, operacionalmente e constitucionalmente, a inclusão no plano de recuperação dos créditos tributários, haja vista o alto custo de transação.

\section{Como citar este documento:}

LANA, Henrique Avelino; PIMENTA, Eduardo Goulart. Análise econômica e o crédito tributário na recuperação judicial. Revista Opinião Jurídica, Fortaleza, v. 19, n. 31, p. 33-74, maio/ago. 2021. 